\title{
MBO-diploma in tijden van crisis : doorleren of werk zoeken?
}

Citation for published version (APA):

Meng, C. M., Huijgen, T. G., \& Ramaekers, G. W. M. (2010). MBO-diploma in tijden van crisis : doorleren of werk zoeken? Researchcentrum voor Onderwijs en Arbeidsmarkt, Faculteit der Economische Wetenschappen. ROA Reports No. 2 https://doi.org/10.26481/umarep.2010002

Document status and date:

Published: 01/01/2010

DOI:

10.26481/umarep.2010002

Document Version:

Publisher's PDF, also known as Version of record

\section{Please check the document version of this publication:}

- A submitted manuscript is the version of the article upon submission and before peer-review. There can be important differences between the submitted version and the official published version of record.

People interested in the research are advised to contact the author for the final version of the publication, or visit the DOI to the publisher's website.

- The final author version and the galley proof are versions of the publication after peer review.

- The final published version features the final layout of the paper including the volume, issue and page numbers.

Link to publication

\footnotetext{
General rights rights.

- You may freely distribute the URL identifying the publication in the public portal. please follow below link for the End User Agreement:

www.umlib.nl/taverne-license

Take down policy

If you believe that this document breaches copyright please contact us at:

repository@maastrichtuniversity.nl

providing details and we will investigate your claim.
}

Copyright and moral rights for the publications made accessible in the public portal are retained by the authors and/or other copyright owners and it is a condition of accessing publications that users recognise and abide by the legal requirements associated with these

- Users may download and print one copy of any publication from the public portal for the purpose of private study or research.

- You may not further distribute the material or use it for any profit-making activity or commercial gain

If the publication is distributed under the terms of Article $25 \mathrm{fa}$ of the Dutch Copyright Act, indicated by the "Taverne" license above, 


\section{MBO-diploma in tijden van crisis}

Doorleren of werk zoeken?

Christoph Meng

Timo Huijgen

Ger Ramaekers

ROA-R-2010/2 


\section{Colofon}

(C) Researchcentrum voor Onderwijs en Arbeidsmarkt (ROA). Niets uit deze uitgave mag op enige manier worden verveelvoudigd zonder voorafgaande schriftelijke toestemming van de directeur van het ROA.

\section{Researchcentrum voor Onderwijs en Arbeidsmarkt}

School of Business and Economics

Maastricht University

\section{Vormgeving}

ROA secretariaat, Maastricht

email: secretary-roa-sbe@maastrichtuniversity.nl

website: www.roa.nl

ISBN: 978-90-532I-483-I

maart 2010 


\section{Inhoud}

Voorwoord

Resumé

vii

1 Inleiding 1

2 Activiteiten van scholen 3

2.1 Inleiding 3

2.2 Omvang van activiteiten $\quad 5$

$\begin{array}{ll}2.3 \text { Invloed van activiteiten } & 11\end{array}$

3 Vervolgonderwijs $\quad 15$

$\begin{array}{lll}3.1 & \text { Inleiding } & 15\end{array}$

$\begin{array}{ll}3.2 \text { Wie zijn de (nieuwe) vervolgstudenten } & 16\end{array}$

$\begin{array}{ll}3.3 \text { Studiekeuze tijdens een economische crisis } & 18\end{array}$

$\begin{array}{ll}3.4 \text { Vervolgopleiding als tussenpauze } & 21\end{array}$

4 Kansen op de arbeidsmarkt $\quad 23$

$\begin{array}{lll}4.1 & \text { Inleiding } & 23\end{array}$

$\begin{array}{ll}4.2 \text { Kans op werk } & 23\end{array}$

$\begin{array}{ll}4.3 \text { Huidige functie } & 30\end{array}$

5 Noch studie noch werk 33

$\begin{array}{lll}5.1 \text { Inleiding } & 33\end{array}$

$\begin{array}{lll}5.2 & \text { Toekomstplannen } & 34\end{array}$

6 Contacten met het UWV 37 



\section{Voorwoord}

Omdat Nederland in een economische malaise verkeert, zijn scholieren van het mbo die in de zomer van 2009 hun eindexamen hebben gedaan middels het School Ex Programma aangespoord om door te leren. Dit om een oplopen van de jeugdwerkloosheid tegen te gaan. Het Ministerie van Onderwijs, Cultuur en Wetenschap, het Ministerie van Sociale Zaken en Werkgelegenheid en het Ministerie van Landbouw, Natuur en Voedselkwaliteit hebben het Researchcentrum voor Onderwijs en Arbeidmarkt (ROA) van Maastricht University gevraagd om, via een Quickscan onder de gediplomeerden, na te gaan hoe het deze gediplomeerden in het eerste half jaar na het behalen van hun diploma is vergaan. In totaal zijn 20.000 jongeren, die het mbo-diploma in het schooljaar 2007-2008 hebben behaald, benaderd. Uiteindelijk hebben ruim 3.200 de vragenlijst op internet ingevuld. In de voorliggende rapportage wordt over dit onderzoek verslag gedaan.

De projectleiding van deze Quickscan berust bij dr. C.M. Meng. Het rapport is geschreven door dr. C.M. Meng, drs. T.G. Huijgen en drs. G.W.M. Ramaekers. De eindredactie is in handen van dr. C.M. Meng. Secretariële ondersteuning is verleend door E.M.H.P. Soudant. Voornoemde personen zijn allen werkzaam bij het ROA. Aan de totstandkoming van het databestand, waarop dit rapport is gebaseerd, werken verder mee drs. M.C.M.Th. van Alphen, drs. J.M.R. van Dongen en drs. B.M. Kinket (allen werkzaam bij DESAN Research Solutions). Speciale dank is gericht aan P. Dijkstra, N. Nijdam, drs. J.D. de Vries en I. Dijkema (allen werkzaam bij de Informatie Beheer Groep te Groningen) voor de medewerking bij het uitzetten van de steekproef onder de gediplomeerden van het mbo.

Een speciaal woord van dank wordt gericht aan de vertegenwoordigers van de financiers die in de klankbordgroep zitting hebben: drs. R. Jongsma (werkzaam bij het Ministerie van Sociale Zaken en Werkgelegenheid), drs. U. Teunis (werkzaam bij het Ministerie van Landbouw, Natuur en Voedselkwaliteit), J.A. de Hoog, drs. drs. B. Verlaan, F. de Graaf (allen werkzaam bij het Ministerie van Onderwijs, Cultuur en Wetenschap). 



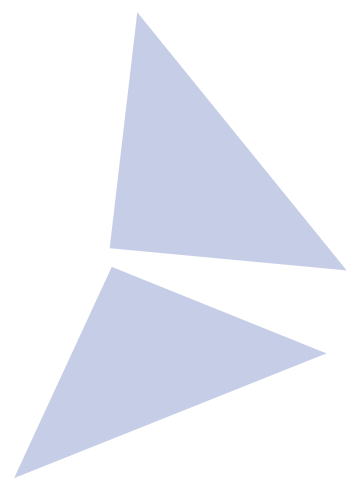

\section{Resumé}

Doorleren of zich aanbieden op de arbeidsmarkt? Jongeren die een mbo-diploma behalen staan voor precies deze keuze. In tijden van een economische malaise, zoals in 2009, krijgt deze afweging nog een zwaardere lading dan in tijden van hoogconjunctuur. De verwachting dat in Nederland de jeugdwerkloosheid tot rond de 150.000 in het najaar van 2009 kon oplopen, heeft in het voorjaar van 2009 dan ook tot een brede aanpak geleid om jongeren aan te sporen om na hun eindexamen door te leren. Maar wat zijn de gevolgen hiervan? Hebben jongeren zich door deze activiteiten laten beïnvloeden? Zien jongeren die aangespoord zijn om door te leren de vervolgopleiding als tussenpauze tot ze een betaalde baan aangeboden krijgen? Hoe verging het de jongeren die zich wel op de arbeidsmarkt hebben aangeboden en welke ondersteuning is aan jongeren geboden die geen werk konden vinden. Navolgend presenteren we kort een aantal conclusies die we kunnen trekken als we ons op de antwoorden van de geënquêteerde jongeren baseren.

\section{Activiteiten van scholen en hun invloed op jongeren}

- In eerste instantie is het zeker cruciaal om vast te stellen dat er in het voorjaar en in de zomer van 2009 in het mbo een breed pallet van activiteiten heeft plaatsgevonden met als doel jongeren te stimuleren om door te leren. Niet al deze activiteiten zullen echt nieuw zijn. Een aantal scholen kende al langer een structurele inzet van activiteiten om jongeren in hun afwegingen te ondersteunen. Maar dit mag niets aan de vaststelling afdoen dat het mbo-veld een grote inspanning heeft geleverd. Scholen hebben daarbij getracht om vooral de meest kwetsbare groep jongeren, de examenkandidaten van de lagere niveaus, te bereiken. Volgens de gediplomeerden is dat ook met succes gebeurd.

- Maar niet alleen mogen we vaststellen dat scholen actief zijn geweest. De resultaten laten ook zien dat hun activiteiten daadwerkelijk een invloed op de jongeren hebben gehad. Op korte termijn is het daarbij gelukt om jongeren te stimuleren om verder te gaan leren. Ook hier is de uitkomst dat de daadwerkelijke invloed het sterkst is op de meest kwetsbare jongeren op de arbeidsmarkt, de jongeren van niveau I en 2 maar zeker ook de jongeren van niet-westerse afkomst. 


\section{Vervolgstudie}

- I5\% van de examenkandidaten van het voorjaar van 2009 heeft zich door activiteiten van scholen laten beïnvloeden en a) is alsnog verder gaan leren (I2\%punt) of b) heeft zijn of haar voorkeur voor een bepaalde vervolgopleiding bijgesteld (3\%-punt).

- De activiteiten en maatregelen die scholen in het voorjaar van 2009 hebben ondernomen om jongeren te stimuleren om door te leren laten een interessant neveneffect zien: Jongeren van niet-westerse afkomst stromen in 2009 relatief vaker door naar een vervolgopleiding en zeker naar een opleiding in het hbo.

- Jongeren uit de meer conjunctuurgevoelige sectoren mbo landbouw, mbo techniek en mbo economie hebben zich bij de keuze voor een bepaalde vervolgopleiding sterker door de recente economische situatie laten beïnvloeden dan jongeren uit de minder conjunctuurgevoelige sectoren mbo gezondheidszorg en mbo gedrag \& maatschappij.

- De groep gediplomeerden van het mbo die 'alsnog' en dankzij de invloed van de school doorgestroomd is naar het hbo kent iets vaker een gemiddeld afstudeercijfer van 7 of lager dan de groep die zonder invloed van de school is doorgestroomd. Het gevaar bestaat dan ook dat er daardoor een relatief grotere groep het hbo is binnengestroomd die eventueel moeite zal kunnen krijgen met het niveau van een hbo-opleiding.

- De economische crisis heeft duidelijk haar sporen achtergelaten wat het aanbod van bbl-leerplaatsen betreft. Bedrijven die in slecht economisch weer terecht zijn gekomen bieden minder snel leerplaatsen aan. Daarom is het aanzienlijk moeilijker geworden voor jongeren van het mbo-bol om de overstap te maken naar het mbo-bbl dan wel voor de jongeren van het mbo-bbl om de opleiding te vervolgen. Het verdient dan ook aanbeveling om de opleidingscapaciteit van de bbl in stand te houden in tijden van economische malaise. Een anticyclische subsidie aan bedrijven zou hierbij kunnen helpen: in tijden van economische bloei de subsidie verlagen om in tijden van economische malaise de subsidie te verhogen zal een stabieler aanbod van bbl-leerplaatsen kunnen garanderen.

- De jongeren die voor een vervolgstudie hebben gekozen zien de studie niet als een tijdelijke, korte termijn oplossing maar willen de studie ook afmaken.

\section{Arbeidsmarkt}

- Van alle mbo-gediplomeerden (schooljaar 2008/2009) die zich op de arbeidsmarkt aanbieden is $13,6 \%$ werkloos. De werkloosheid varieert sterk tussen opleidingsniveaus en tussen de gevolgde leerweg:

- De werkloosheid is het hoogst onder de lagere opleidingsniveaus.

- De werkloosheid is aanzienlijk hoger onder de gediplomeerden van het mbo-bol in vergelijking met de gediplomeerden van het mbo-bbl. 
- Niet-westerse allochtonen kennen een aanzienlijk moeilijkere start op de arbeidsmarkt, wat gedeeltelijk het gevolg is van a) een oververtegenwoordiging in de lagere opleidingsniveaus en b) een oververtegenwoordiging in het mbo-bol.

- De provincies Limburg, Noord-Holland, Zuid-Holland, Flevoland en Drenthe kennen een werkloosheidspercentage van boven de $15 \%$. In deze provincies onderhoudt het UWV ook relatief meer contacten met jongeren.

\section{Jongeren zonder werk en zonder vervolgstudie}

- Bijna één op de vijf jongeren begint binnenkort met een opleiding of een nieuwe baan.

- Vooral de hoge kosten, de noodzaak om een inkomen te hebben en het feit dat men liever wil werken houdt het overgrote deel van deze jongeren tegen om aan een nieuwe opleiding te beginnen. Het niet doorstromen naar een vervolgopleiding kent daarmee een duidelijke financiële component.

- Door betere studiekeuzebegeleiding en activiteiten voor meer bbl-leerplaatsen zijn nog wel wat jongeren alsnog voor een vervolgopleiding te winnen.

- Een op de vier jongeren zonder werk en zonder vervolgstudie zou het fijn vinden als het UWV hen benaderde en hulp ging bieden. Probleem is echter dat het gros van deze jongeren geen toestemming aan de school heeft gegeven om hun gegevens aan het UWV door te geven. Examenkandidaten dienen dan ook overtuigd te worden van de voordelen dat de school hun gegevens mag doorgeven aan het UWV.

- Een op de vijf jongeren zonder werk en zonder vervolgstudie vindt het spijtig dat hij of zij geen contacten meer heeft met de oude school. Gezien het belang om deze jongeren aan een vervolgopleiding te helpen, dienen scholen dan ook in hun alumnibeleid verder gestimuleerd te worden. 



\section{Inleiding}

Doorleren of zich aanbieden op de arbeidsmarkt? Jongeren die een mbo-diploma behalen staan voor precies deze keuze. Met uitzondering van een diploma op niveau I biedt een mbo-diploma namelijk a) een startkwalificatie om een arbeidsmarktloopbaan te beginnen en b) de mogelijkheid om kennis en vaardigheden verder te ontwikkelen in een vervolgopleiding: zij het in het mbo zelf of, na het behalen van een mbo-diploma op niveau 4, in het hbo. In tijden van een economische malaise, zoals in 2009 , kent deze afweging nog een zwaardere lading dan in tijden van hoogconjunctuur. De mbo-gediplomeerden van het schooljaar 2008/2009 zijn zich hier zeker van bewust (zie tabel I.I). Zo denkt een op de drie van deze jongeren dat de economische malaise van 2009 direct invloed heeft gehad op hun persoonlijke situatie. Bijna de helft geeft aan dat de economische situatie hun kansen op de arbeidsmarkt heeft beïnvloed. Maar ook in de afweging tussen doorleren en aanbieden op de arbeidsmarkt zien we de economische situatie terug. Bijna een op de drie heeft zich door de economische situatie laten beïnvloeden bij deze keuze, en bij 20\% was er een invloed op de keuze voor een bepaalde vervolgopleiding.

Tabel 1.1

Heeft de recente economische situatie in Nederland invloed gehad op...

\begin{tabular}{|c|c|c|c|c|c|}
\hline $\begin{array}{l}\text { Kansen op de } \\
\text { arbeidsmarkt }\end{array}$ & $\begin{array}{c}\text { Keuze voor } \\
\text { bepaalde } \\
\text { beroep/ } \\
\text { werkgever }\end{array}$ & $\begin{array}{l}\text { Inhoud van het } \\
\text { huidige werk }\end{array}$ & $\begin{array}{c}\text { Keuze om wel } \\
\text { of niet door te } \\
\text { leren }\end{array}$ & $\begin{array}{c}\text { Keuze voor } \\
\text { bepaalde } \\
\text { vervolgopleiding }\end{array}$ & $\begin{array}{l}\text { Persoonlijke } \\
\text { situatie }\end{array}$ \\
\hline
\end{tabular}

$\begin{array}{lllllll}\text { Ja }(\%) & 48 & 30 & 30 & 29 & 20 & 34\end{array}$

Bron: Quickscan 2009, ROA

De verwachting dat in Nederland de jeugdwerkloosheid tot rond de 150.000 in het najaar van 2009 kon oplopen, heeft in het voorjaar van 2009 dan ook terecht tot een brede aanpak geleid om jongeren aan te sporen om na hun eindexamen door te leren. Centraal stond daarbij het School Ex Programma.

In het voorliggende rapport analyseren we een aantal aspecten dat centraal staat in de keuze tussen doorleren en aanbieden op de arbeidsmarkt. Zo gaan we in op de omvang van de activiteiten die scholen hebben ondernomen. Ook stellen we de vraag of de scholen, gezien hun beperkt budget qua zowel tijd als geld, een effectieve aanpak van de activiteiten hebben laten zien, en wat de invloed van deze activiteiten is geweest 
op de afweging die jongeren maken. Maar we vragen ons ook af of de jongeren die aangespoord zijn om door te leren de vervolgopleiding slechts als tussenpauze zien tot ze een betaalde baan aangeboden krijgen. We gaan na hoe het de jongeren die zich op de arbeidsmarkt hebben aangeboden is vergaan en vragen welke ondersteuning aan jongeren die geen werk vonden is geboden.

De resultaten in het voorliggende rapport zijn afkomstig van een steekproef onder 20.000 gediplomeerden van het mbo (examenjaar 2009). In totaal hebben 3.200 jongeren de internetenquête ingevuld. In dit rapport worden de resultaten (tenzij anders vermeld) op basis van gewogen aantallen (d.w.z. naar populatie opgehoogde aantallen en voor eventuele responsverschillen tussen bijvoorbeeld mannen en vrouwen gecorrigeerd) gepresenteerd.

Het rapport is als volgt opgebouwd: In hoofdstuk 2 staan we stil bij de vragen rondom de activiteiten die scholen in het voorjaar ondernomen hebben om jongeren langer op school te houden. Ook analyseren we of deze activiteiten de gewenste uitkomst hebben opgeleverd. In hoofdstuk 3 gaan we meer in detail in op de jongeren die voor een vervolgopleiding hebben gekozen, en in hoofdstuk 4 en 5 staan de jongeren centraal die zich met al dan niet succes op de arbeidsmarkt hebben aangeboden. Tot slot staan we in hoofdstuk 6 stil bij een aantal vragen over de contacten die de jongeren hebben of hebben gehad met het UWV. 


\section{Activiteiten van scholen}

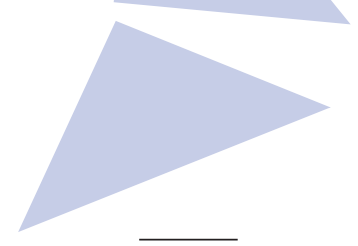

\subsection{Inleiding}

Jongeren stimuleren om verder te gaan leren. Dit is het centrale onderdeel van het School Ex Programma dat in het kader van het Actieplan Jeugdwerkloosheid in het voorjaar van 2009 van start is gegaan. Het School Ex Programma bestaat in hoofdlijnen uit twee elementen, namelijk een registratie van de toekomstplannen van examenkandidaten (de zogenaamde 'mobiliteitsregistratie') en het bieden van (individuele) opleidingsadviezen. De mobiliteitsregistratie dient in beeld te brengen wat examenkandidaten na het behalen van hun diploma van plan waren te gaan doen. Hierbij werd aan de examenkandidaten via een korte enquête gevraagd aan te geven of zij:

- verder gingen doorleren in het mbo of het hbo en ook al een keuze hadden gemaakt voor een vervolgopleiding

- van plan waren het onderwijs te verlaten en al in bezit van een arbeidscontract waren

- van plan waren het onderwijs te verlaten zonder in bezit van een arbeidscontract te zijn

- nog twijfelden tussen 'aanbieden op de arbeidsmarkt' en 'doorleren'

Doelstelling was door deze enquête een bijna sluitende registratie van de examenkandidaten en hun toekomstplannen op te stellen. Gaan we af op de antwoorden van de Quickscan respondenten, dan heeft 85\% deze enquête ingevuld. Slechts I\% is door de school gevraagd maar heeft geen antwoord gegeven, en I4\% geeft aan dat de school deze vraag niet heeft gesteld. Aangezien in de steekproef echter ook jongeren zitten die hun examen in het begin van 2009 hebben gedaan, en daarmee voordat het School Ex Programma van start ging, mag vastgesteld worden dat de respons op de enquête hoog was en een eerste doel daarmee bereikt is. $46 \%$ van de Quickscan respondenten gaf aan dat zij op de kaart ingevuld hadden dat zij verder gingen leren en $24 \%$ dat zij van plan waren het onderwijs te verlaten aangezien zij al in het bezit van een arbeidscontract waren. IO\% was van plan het onderwijs te verlaten zonder in het bezit van een arbeidscontract te zijn, en slechts $5 \%$ twijfelde nog tussen 'aanbieden op de arbeidsmarkt' en 'doorleren'.

Zeker de jongeren die in de categorie 3 en 4 vallen dienen aangemerkt te worden als de risicogroep. De uitkomsten van de enquête onder deze jongeren zijn dan ook, indien 
zij hiervoor toestemming hebben gegeven, doorgeleid naar het UWV Werkbedrijf zodat het UWV Werkbedrijf zo spoedig mogelijk een optimaal inzicht heeft gekregen in de (potentiële) toestroom van schoolverlaters zonder werk uit het beroepsonderwijs en snel en adequaat heeft kunnen inspelen op behoeften van deze categorieën jongeren door hen na de zomervakantie een bemiddelingstraject aan te bieden. Gaan we ook hier op de antwoorden van onze respondenten af, dienen we vast te stellen dat het UWV met deze opzet in een moeilijke situatie is gebracht. Immers, slechts $23 \%$ van de Quickscan respondenten geeft aan dat ze de school toestemming hebben verleend om hun gegevens aan het UWV door te geven. Opvallend is daarbij dat in de groep die nog twijfelde met betrekking tot hun directe toekomstplannen het percentage dat toestemming gaf (30\%) niet veel hoger ligt. Hiermee dient zeker in het vervolg van het School Ex Progamma, zoals het in 2010 wordt opgezet, rekening te worden gehouden. We komen in hoofdstuk 6 nog uitgebreid op dit punt terug.

Naast deze mobiliteitsregistratie diende de tweede peiler, 'opleidingsadviezen', het fundament van het School Ex Programma te verstevigen. Dit werd zoveel mogelijk in direct persoonlijk contact met de examenkandidaten (klas, mentorgroep, loopbaangesprek, diploma-uitreiking) afgenomen, zodat de studenten gerichte adviezen vanuit de school konden krijgen (het zogenoemde 'opleidingsadvies') en gemotiveerd konden worden om langer door te leren.

Scholen kennen nog een groot aantal andere mogelijkheden om jongeren te stimuleren om verder te gaan leren. Zo kan verspreiding van informatie (via brochures, via de schoolwebsite of in het kader van extra bijeenkomsten) van belang zijn. Daarnaast spelen docenten een belangrijke rol. Door hun directe contact met de jongeren zijn zij bijvoorbeeld in staat om op een eenvoudige manier actuele informatie over de arbeidsmarktomstandigheden aan te bieden. Versterkt aandacht besteden aan de risico's verbonden aan het aanbieden op de arbeidsmarkt tijdens een recessie (hogere kans op werkloosheid of een baan van laag niveau) kan jongeren ertoe bewegen om deze stap nog een keer te overdenken.

Een van de doelstellingen van het in dit rapport gepresenteerde onderhavige onderzoek was dan ook om inzicht te krijgen in de aanpak waarvoor het mbo in het voorjaar van 2009 heeft gekozen en in de invloed van de activiteiten op de keuze tussen 'aanbieden op de arbeidsmarkt' aan de ene kant en 'verder gaan leren in het onderwijs' aan de andere kant.

Hiertoe is aan de respondenten gevraagd om voor een aantal expliciet genoemde activiteiten aan te geven of hun school deze heeft aangeboden. In eerste instantie waren dit een drietal meer algemene activiteiten, namelijk:

- extra informatiebrochures uitgedeeld of extra informatie op website geplaatst,

- extra informatiebijeenkomsten gehouden,

- extra aandacht besteed door docenten aan de huidige problemen op de arbeidsmarkt. 
Daarnaast is aan de respondenten gevraagd of ze voor of na het invullen van de mobiliteitsregistratie (de School-Ex kaart) hun toekomstplannen met iemand van het ROC persoonlijk hebben besproken. Meer in detail is aan de respondenten gevraagd of ze:

- een persoonlijk gesprek over toekomstplannen hadden,

- een persoonlijk adviesgesprek over mogelijke vervolgopleidingen hadden,

- een persoonlijk adviesgesprek over arbeidsmarktkansen hadden.

Bij al de gevraagde activiteiten is aan de respondenten vermeld dat de vraag betrekking had op 'extra' activiteiten die de school in het kader van de economische malaise van 2009 eventueel heeft uitgevoerd. Echter, precies op dit punt dient een aantal kanttekeningen gemaakt te worden.

- Ten eerste dienen we er rekening mee te houden dat scholieren activiteiten van de school eventueel niet als 'extra' activiteit hebben ondervonden maar deze als een reguliere activiteit zagen.

- Ten tweede dienen we op te merken dat het zich bij de activiteiten in de vragenlijst om een relatief begrensde lijst van mogelijke activiteiten handelde. Het bezoeken van informatiedagen van hogescholen of van banenmarkten waar de scholieren in contact kunnen komen met potentiële aanbieders van opleidingen en banen is bijvoorbeeld een alternatieve maatregel.

- Ten derde dienen we er rekening mee te houden dat een persoonlijk adviesgesprek alleen kan plaatsvinden indien de scholier hieraan meewerkt.

We dienen dan ook met deze punten rekening te houden bij de interpretatie van de resultaten. Zeker omdat alle drie punten de kans verhogen dat de resultaten minder schoolactiviteiten laten zien dan in werkelijkheid hebben plaatsgevonden. Indien een respondent dan ook geen van de opgenomen activiteiten heeft vermeld, kan dit nimmer gelijk gezet worden met het resultaat dat de school 'geen enkele extra activiteit' heeft ondernomen. Ondanks deze relativerende opmerkingen bieden de navolgende analyses een interessant inzicht in een tweetal aspecten: ten eerste (paragraaf 2.2) in de mate waarin scholen op korte termijn (in de periode mei tot en met juli 2009) met een begrensd budget (zowel qua tijd als geld) actief zijn geweest om jongeren te stimuleren om verder te gaan leren en ten tweede (paragraaf 2.3) in de mate waarin deze activiteiten het gewenste doel bereikt hebben.

\subsection{Omvang van activiteiten}

Wat is de omvang van de activiteiten die volgens de examenkandidaten hebben plaatsgevonden? Waren de activiteiten gericht op specifieke groepen van examenkandidaten of niet? De tweede vraag is daarbij van belang aangezien eerder onderzoek (zie bijvoorbeeld ROA, 2009: Schoolverlaters tussen onderwijs en arbeidsmarkt 2008) heeft laten zien dat niet iedereen die het mbo met diploma verlaat dezelfde problemen kent tijdens de transitie van onderwijs naar arbeidsmarkt. De gediplomeerden van de lagere niveaus en van conjunctuurgevoelige opleidingssectoren maar ook allochtone 
jongeren kennen in het algemeen, maar nog duidelijker tijdens economisch zwaar weer, een hoger risico op werkloosheid.

Tenzij anders vermeld, concentreren we ons in dit hoofdstuk op de jongeren die in de periode mei tot en met juli hun eindexamen hebben behaald. In deze tijdsperiode is het School Ex Programma uitgevoerd. Er kan echter vastgesteld worden dat de resultaten kwalitatief overeind blijven als de eindexamenkandidaten van de eerdere maanden van het schooljaar 2008/2009 in de analyses meegenomen worden.

Figuur 2.I geeft een eerste inzicht in de activiteiten die volgens de gediplomeerden hebben plaatsgevonden. We onderscheiden daarbij een viertal mogelijkheden:

- Er heeft uitsluitend een algemene activiteit plaatsgevonden zoals het verspreiden van informatie via brochures of website, het organiseren van extra bijeenkomsten op school of het besteden van extra aandacht door docenten aan de arbeidsmarktproblematiek.

- Er heeft uitsluitend een persoonlijk gesprek over de toekomstplannen plaatsgevonden.

- Er heeft een combinatie van algemene activiteit en persoonlijk gesprek plaatsgevonden.

- Er heeft geen extra activiteit plaatsgevonden.

Figuur 2.1

Activiteiten per leerweg

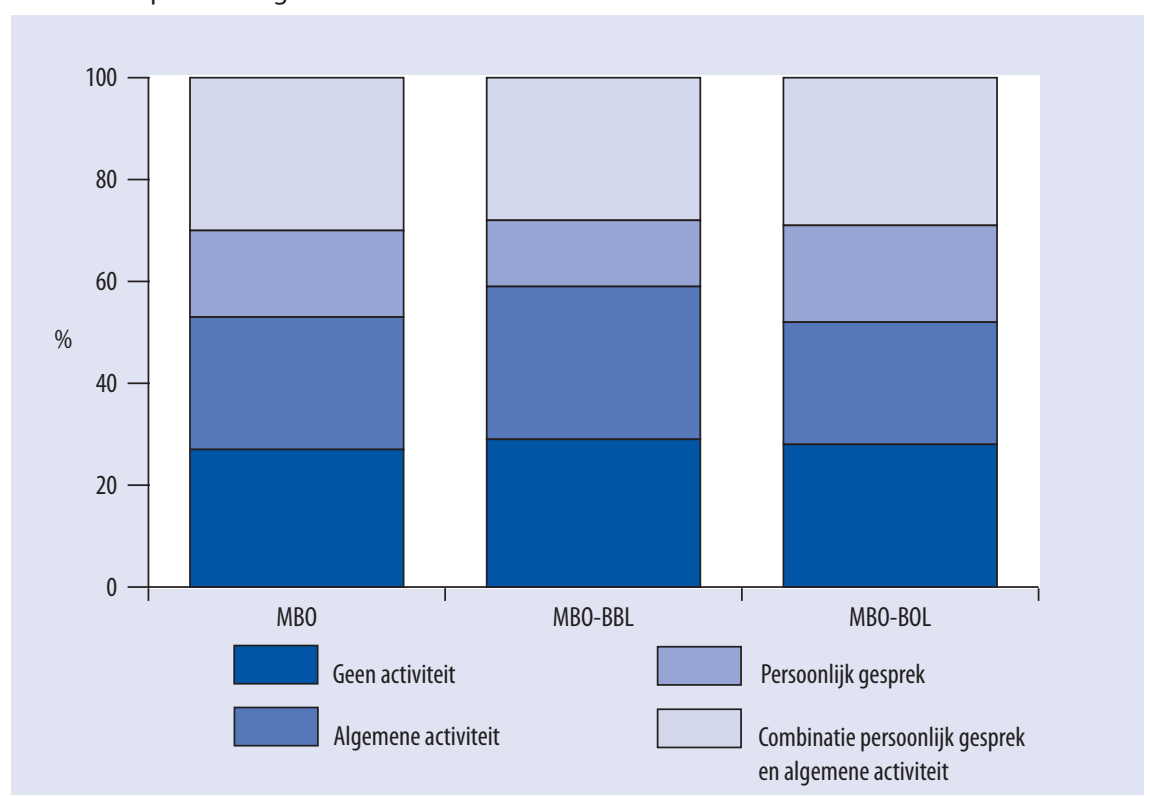

Bron: Quickscan 2009, ROA 
Minder dan 30\% (27\%) van de gediplomeerden meldt dat geen van de gevraagde activiteiten heeft plaatsgevonden. Gezien onze eerdere kanttekeningen met betrekking tot het melden van activiteiten door respondenten, dient dit als een uitermate laag percentage geïnterpreteerd te worden. Scholen hebben blijkbaar een aanzienlijke inspanning geleverd in de eerste helft van 2009 of kennen al langer een traditie met een uitgebreid pakket van activiteiten die jongeren dienen te stimuleren om verder te gaan leren. Hierbij doet zich geen verschil voor tussen jongeren die tijdens hun opleiding relatief gezien vaak in een bedrijf werkzaam waren (mbo-bbl) en jongeren die het gros van hun opleidingstijd in het schoolgebouw (mbo-bol) hebben doorgebracht.

Richten we onze aandacht op de jongeren die een extra activiteit hebben vermeld, dan valt direct het hoge percentage op dat een persoonlijk gesprek over hun toekomstplannen had, namelijk 47\%. Het merendeel van deze jongeren (30\%-punt) kende daarbij een combinatie van een persoonlijk gesprek en een algemene activiteit. Aangezien een persoonlijk gesprek alleen kan plaatsvinden indien de scholier hieraan meewerkt, kunnen we ervan uitgaan dat scholen een persoonlijk gesprek met meer dan 50\% van de jongeren ambieerden. Doordat jongeren tijdens hun studie in het mbo-bol aanzienlijk vaker fysiek op school zijn dan jongeren die de opleiding in het mbo-bbl volgen, is het niet echt verrassend dat bij de eerste groep jongeren $(48 \%)$ iets vaker een persoonlijk gesprek plaats heeft gevonden. Maar ook hier is het opmerkelijk dat van de jongeren van het mbo-bbl nog steeds zo'n $40 \%$ een persoonlijk gesprek vermeldt. Tot slot vermeldt $43 \%$ dat er een algemene activiteit (deels in combinatie met en deels zonder persoonlijk gesprek) heeft plaatsgevonden.

\section{Tekstbox 2.1}

Activiteitsverschillen tussen ROC's

Interessant is de vraag of er tussen de verschillende aanbieders van mbo-opleidingen grote verschillen te vinden zijn. Gezien de omvang van de steekproef dienen we hier echter voorzichtig te zijn. Voor 38 RoC's zijn de aantallen respondenten voldoende om een eerste voorzichtige indicatie te geven. Van deze ROC's lijkt slechts een klein deel zich duidelijk positief dan wel negatief van het landelijk beeld te onderscheiden. Zo is er een viertal ROC's waar (bijna) $80 \%$ van de respondenten een activiteit vermeldt, en vinden we een tweetal ROC's waar (bijna) $70 \%$ van de respondenten een persoonlijk gesprek had. Hiertegenover staat dat slechts bij acht van deze 38 ROC's minder dan $60 \%$ van de respondenten een activiteit vermeldt, en zien we dat bij vijf ROC's minder dan $40 \%$ een persoonlijk gesprek had. Tot slot lijkt het erop dat ROC's met een traditie van structureel goede voorlichting over vervolgonderwijs ook in het voorjaar/zomer van 2009 relatief gezien actiever waren. Een gecombineerde analyse van het oordeel van mbo-gediplomeerden in eerdere jaren met betrekking tot de voorlichting over mogelijke vervolgopleidingen en de antwoorden van de Quickscan respondenten met betrekking tot de geboden activiteiten laat namelijk op ROC niveau een positieve relatie tussen deze twee antwoorden zien.

De keuze tussen 'aanbieden op de arbeidsmarkt' en 'verder leren in het onderwijs' verschilt, afhankelijk van het niveau van de gevolgde opleiding. Zeker in tijden van een recessie lopen jongeren met een diploma op niveau I of 2 een aanzienlijk hoger risico op werkloosheid. Figuur 2.2 laat dit aan de hand van de werkloosheidscijfers onder gediplomeerden van het mbo-bol duidelijk zien. De periode 1999 tot en met 2008 kan in drie subperiodes onderverdeeld worden: (I) de periode $1999-2000$ met 
een sterke economische groei, (2) de periode 200I-2005 met een zwakke economische groei en (3) de periode 2006-2008 met een sterk aantrekkende economische groei.

Figuur 2.2

Werkloosheid onder recent gediplomeerden van het mbo-bol (meetpunt ca. 1 jaar na afstuderen)

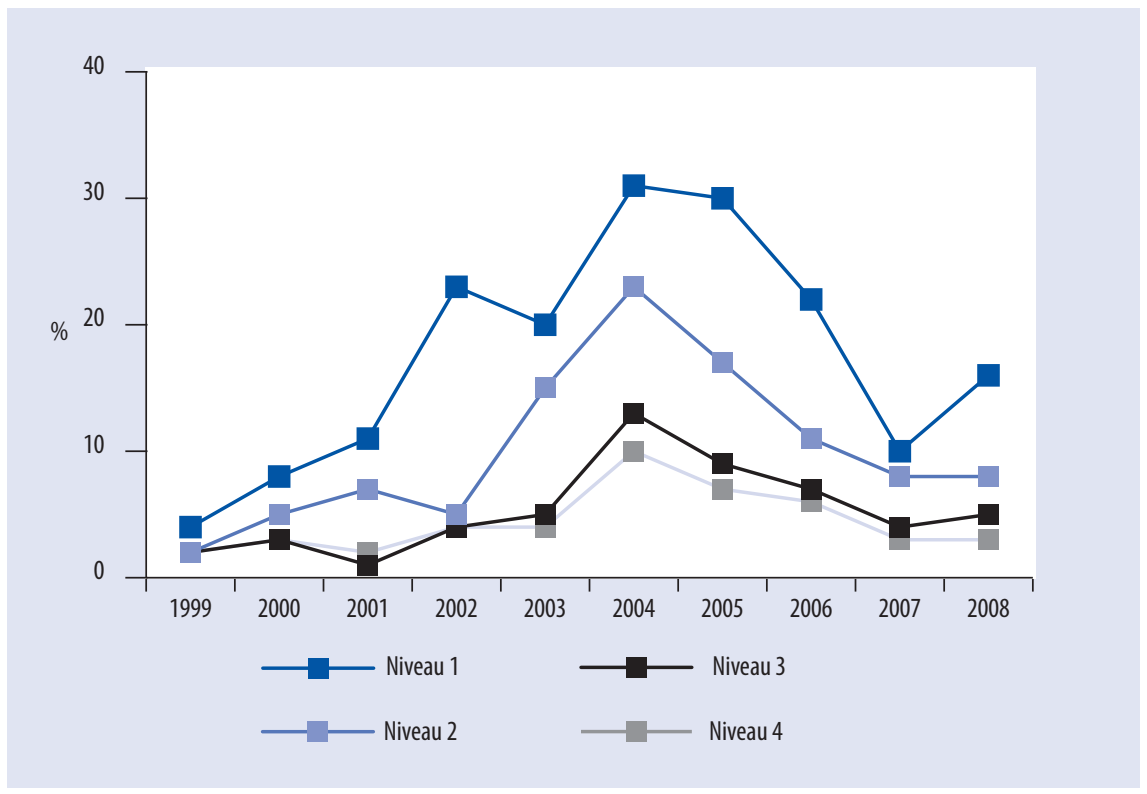

Bron: SIS, 1999-2008, ROA

Simpelweg gesproken, dienen we vast te stellen dat activiteiten om jongeren op school te houden in tijden van crisis vooral gericht dienen te worden op de examenkandidaten in het funderende onderwijs (de niveaus I en 2). Figuur 2.3 laat zien dat dit ook inderdaad de aanpak van het mbo in het voorjaar van 2009 was. Minder dan I op de 5 gediplomeerden van het mbo niveau I vermeldt geen extra activiteiten. Tegelijkertijd heeft $61 \%$ van deze groep jongeren een persoonlijk gesprek gehad over zijn of haar toekomstplannen. Terwijl het percentage met een persoonlijk gesprek afneemt naarmate het niveau hoger wordt (op niveau 4 is het net iets minder dan 40\%), loopt het percentage dat geen activiteit vermeldt op naar rond I op de 3. Kennelijk hebben ROC's hun beperkte middelen qua tijd en geld getracht zo effectief mogelijk in te zetten voor de meest kwetsbare groep: de jongeren die trachten zonder startkwalificatie de arbeidsmarkt op te gaan dan wel met een diploma op niveau 2. 
Figuur 2.3

Activiteiten per opleidingsniveau

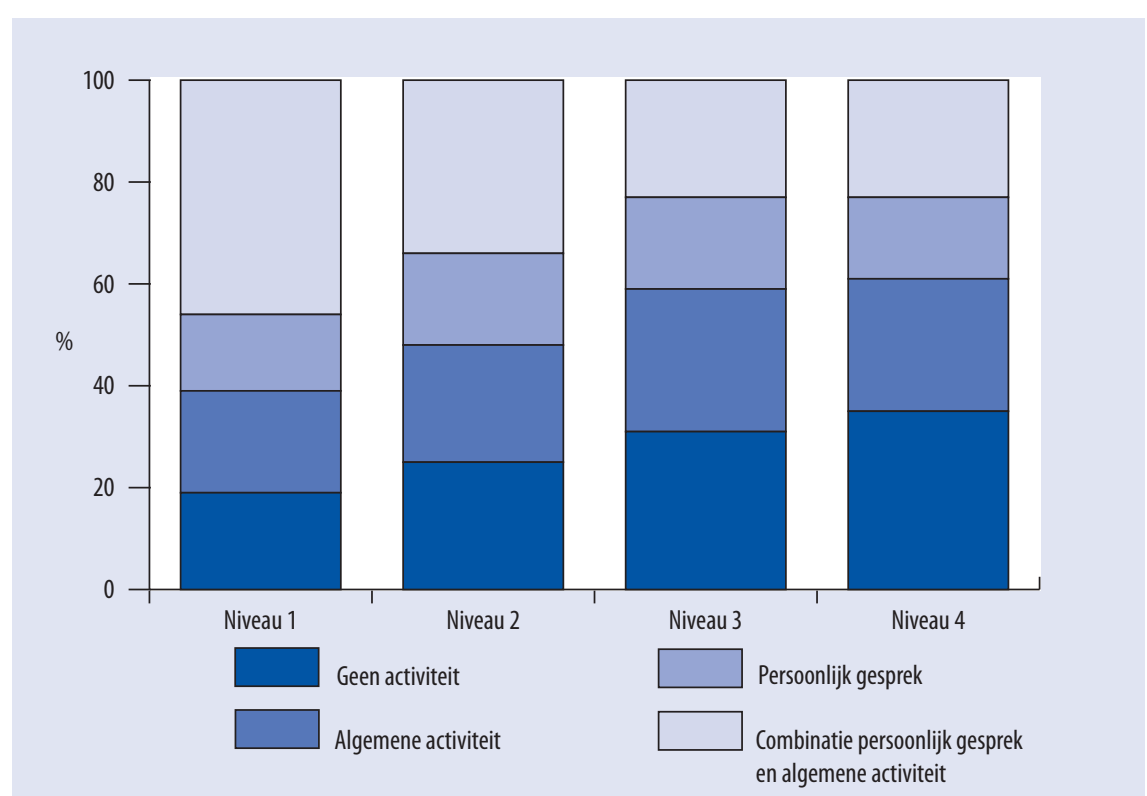

Bron: Quickscan 2009, ROA

Naast het niveau van de opleiding vormt de opleidingssector een factor die mede de kansen op de arbeidsmarkt, specifiek in tijden van laagconjunctuur, bepaalt. Wat de conjunctuurgevoeligheid van opleidingssectoren in het mbo betreft, biedt tabel 2.I een directe indicatie ${ }^{\mathrm{I}}$ aan de hand van de voor de periode 2009-2013 verwachte gemiddeld jaarlijkse groei van de uitbreidingvraag voor opleidingscategorieën op mbo-niveau.

\section{Tabel 2.1}

Gemiddeld jaarlijkse groei van de uitbreidingsvraag, prognose 2009-2013 (\%)

\begin{tabular}{lr} 
mbo groen & $-1,0$ \\
\hline mbo techniek & $+0,1$ \\
\hline mbo sociaal-cultureel & $+0,3$ \\
\hline mbo gezondheidszorg & $+0,7$ \\
\hline mbo economie & $-0,9$
\end{tabular}

Bron: ROA (Arbeidsmarktinformatiesysteem)

Tabel 2.I laat zien dat voor middelbaar opgeleiden de uitbreidingsvraag behoorlijk kan verschillen. $Z_{o}$ is de gemiddelde jaarlijkse groei voor mbo groen en mbo economie sterk negatief, terwijl er voor mbo techniek een kleine positieve uitbreidingsvraag en

I. ROA (2009), De arbeidsmarkt naar opleiding en beroep tot 2014, Maastricht: Researchcentrum voor Onderwijs en Arbeidsmarkt. 
voor mbo sociaal-cultureel en vooral mbo gezondheidszorg een sterk positieve uitbreidingsvraag voorzien wordt. De situatie is daarbij naar verwachting bijzonder problematisch voor de sector economie. Deze sector kent, in tegenstelling tot de sector landbouw, ook nog een lage vervangingsvraag. De vraag stelt zich dan in hoeverre ROC's in hun activiteiten op deze verschillen ingespeeld hebben. Zeker op het niveau van de docenten bestaan er immers kansen om scholieren in specifieke opleidingen over kansen en risico's op de arbeidsmarkt te informeren. Ook wat dit aspect betreft laten de resultaten een eenduidig beeld zien. Vermeldt van de gediplomeerden uit de mbo sectoren gezondheidszorg en sociaal-cultureel minder dan I op de 4 dat docenten extra aandacht aan de situatie op de arbeidsmarkt hebben besteed, is dit in de mbo sectoren economie, groen en techniek I op de 3. Met andere woorden, vergelijkbaar met de activiteiten per niveau vinden we dat het precies de docenten in de conjunctuurgevoelige sectoren zijn die extra aandacht hebben besteed aan de arbeidsmarkt. Echter dienen we dit keer ook nadrukkelijk vast te stellen dat het percentage respondenten dat deze extra aandacht vermeldt nogal klein is. Immers, volgens de gediplomeerden heeft zelfs in tijden van een economische periode van extreme laagconjunctuur gemiddeld minder dan I op de 3 docenten extra aandacht aan de arbeidsmarkt besteed.

Algemene activiteiten zoals brochures zijn effectieve middelen om een brede en vaak heterogene groep jongeren te bereiken. Extra aandacht voor de arbeidsmarktsituatie tijdens de les vormt een eenvoudige toegang tot een homogenere groep jongeren die als gemeenschappelijke deler dezelfde opleiding volgen. Echter, om binnen de laatstgenoemde groep de meest kwetsbare individuen van gerichte informatie te voorzien, dient men het persoonlijke gesprek aan te gaan. Om vast te stellen in welke mate dit dan ook is gebeurd, is een logistische analyse uitgevoerd op de kans dat de respondent vermeldt dat er een persoonlijk gesprek heeft plaatsgevonden. Voordeel van deze analyse is dat we daarbij kunnen controleren voor bijvoorbeeld het niveau of de sector van de opleiding die de respondent heeft gevolgd. Dit is belangrijk aangezien bijvoorbeeld het percentage jongeren van allochtone afkomst sterk verschilt tussen zowel de opleidingsniveaus als de opleidingssectoren. De resultaten van de analyse op de kans dat er een persoonlijk gesprek over de toekomstplannen van de jongeren heeft plaatsgevonden, laten zien dat er geen significante verschillen te vinden zijn tussen bijvoorbeeld jongeren van allochtone afkomst en autochtone jongeren. Ook zien we geen significante verschillen tussen jongens en meisjes. Echter, ook hier vinden we een heel sterk effect van het opleidingsniveau. Persoonlijke gespreken hebben inderdaad, zoals we eerder al vermeld hebben, in aanzienlijk hogere mate met jongeren van de lagere niveaus plaatsgevonden. Aangezien jongeren van allochtone afkomst relatief sterk oververtegenwoordigd zijn in opleidingen op lager niveau, laat een rechte telling zien dat een hoger percentage van allochtone jongeren een persoonlijk gesprek kende in vergelijking met de autochtone jongeren. Dit is echter een effect van het opleidingsniveau en niet van de etniciteit. 


\subsection{Invloed van activiteiten}

Meten dat scholen activiteiten hebben uitgevoerd om jongeren te stimuleren om verder te gaan leren is een aspect. Vaststellen dat deze activiteiten ook echt invloed op de keuze tussen 'aanbieden op de arbeidsmarkt' en 'doorleren in het onderwijs' hebben, is echter de belangrijkere toets.

Voordat we hier in meer detail bij stilstaan, laat tabel 2.2 zien dat $12 \%$ van de jongeren dankzij de activiteiten die de scholen hebben ondernomen alsnog verder is gaan leren. $\mathrm{Bij}$ nog eens $3 \%$ heeft het tot een verandering van de gekozen vervolgopleiding geleid, en bij eveneens $3 \%$ had het een ander effect. In totaal hebben de activiteiten van de scholen dus bijna I op de 5 examenkandidaten beïnvloed. De invloed heeft er in het algemeen ook nadrukkelijk toe geleid dat deze jongeren een duidelijk hogere kans hebben om een vervolgopleiding te gaan volgen. Zo volgen bijna 4 op de 5 jongeren die door de school beïnvloed zijn een vervolgopleiding, terwijl dit bij de groep die zegt dat ze niet beïnvloed zijn minder dan de helft $(44 \%)$ is.

Tabel 2.2

Effect van schoolactiviteiten op de bestemming van gediplomeerden, naar opleidingsniveau (\%)

$\begin{array}{lccccc} & \text { Niveau 1 } & \text { Niveau 2 } & \text { Niveau 3 } & \text { Niveau 4 } & \text { Totaal } \\ \text { Nee, geen invloed } & 61 & 75 & 85 & 90 & 82 \\ \text { Ja, ik ben alsnog verder gaan leren } & 26 & 16 & 11 & 6 & 12 \\ \begin{array}{l}\text { Ja, ik heb een andere opleiding gekozen dan ik } \\ \text { eerst van plan was }\end{array} & 9 & 4 & 1 & 1 & 3 \\ \text { Ja, anders } & 4 & 5 & 3 & 3 & 3\end{array}$

Bron: Quickscan 2009, ROA

De resultaten in tabel 2.2 laten verder zien dat de invloed van de school lijkt af te nemen naarmate het opleidingsniveau van de gediplomeerde hoger is. Zo zijn de gediplomeerden van niveau I ruim 4 keer vaker $(26 \%)$ alsnog verder gaan leren dan de gediplomeerden van niveau $4(6 \%)$. Ook het percentage van de gediplomeerden dat voor een andere opleiding heeft gekozen is aanzienlijk hoger op niveau I en 2 dan op niveau 3 en 4 . Dit heeft dan ook tot gevolg dat in totaal rond $40 \%$ van niveau I gediplomeerden aangeeft door de activiteiten op school beïnvloed te zijn. Dit percentage daalt naar $25 \%$ op niveau 2 , I5\% op niveau 3 en uiteindelijk naar IO\% op niveau 4.

Naast het niveau speelt echter ook de etnische afkomst van de examenkandidaat een belangrijke rol in de vraag of de schoolactiviteiten de keuze hebben beïnvloed. Tabel 2.3 laat zien dat de activiteiten die scholen in het voorjaar van 2009 hebben ondernomen aanzienlijk vaker invloed hebben gehad op wat niet-westerse allochtonen na de opleiding zijn gaan doen dan op wat westerse allochtonen en autochtonen na de opleiding zijn gaan doen. Zo geeft $24 \%$ van de niet-westerse allochtonen aan dat ze alsnog verder zijn gaan leren. Onder de westerse allochtonen is dit $14 \%$ en onder de autochtone examenkandidaten minder dan I op de Io (9\%). 
Tabel 2.3

Effect van schoolactiviteiten op de bestemming van gediplomeerden, naar etniciteit (\%)

\begin{tabular}{lcccc} 
& $\begin{array}{c}\text { Westerse } \\
\text { allochtonen }\end{array}$ & $\begin{array}{c}\text { Niet-westerse } \\
\text { allochtonen }\end{array}$ & Autochtonen & Totaal \\
\hline Nee, geen invloed & 81 & 65 & 85 & 82 \\
\hline Ja, ik ben alsnog verder gaan leren & 14 & 24 & 2 & 3 \\
\hline $\begin{array}{l}\text { Ja, ik heb een andere opleiding } \\
\text { gekozen dan ik eerst van plan was }\end{array}$ & 1 & 6 & 3 & 3 \\
\hline Ja, anders & 3 & 4 & 2 & 3
\end{tabular}

Bron: Quickscan 2009, ROA

Echter, voordat we hier conclusies uit trekken, dienen we deze uitkomsten verder te analyseren. We hebben eerder al laten zien dat de niet-westerse allochtonen relatief oververtegenwoordigd zijn in de niveaus I en 2, en dat we daarom het gevaar lopen om het effect van deze groep te verwisselen met het effect van het niveau van de gevolgde opleiding. Om hier meer inzicht in te verschaffen, staan we in wat volgt dan ook kort stil bij een tweetal uitgebreidere analyses (zie tabel 2.4). De analyses geven een antwoord op de vraag of de activiteiten, en meer in detail welke specifieke activiteiten, de jongeren beïnvloed hebben. Analyse I gaat in op de vraag of de activiteiten de jongeren in het algemeen bij hun keuzes hebben beïnvloed, en analyse 2 gaat in op de vraag of de activiteiten de jongeren zodanig beïnvloed hebben dat ze inderdaad verder zijn gaan leren.

De analyses laten zien dat niet-westerse allochtonen aanzienlijk vaker beïnvloed zijn dan westerse allochtonen of autochtonen, en dat de invloed afneemt naarmate het onderwijsniveau hoger is. De resultaten kunnen als positief bestempeld worden omdat zowel de niet-westerse allochtonen als de gediplomeerden van de 'lage' opleidingsniveaus in tijden van crisis aanzienlijk minder kansen op de arbeidsmarkt hebben. Overigens blijkt het geslacht geen significant effect te hebben. Dit betekent dat jongens en meisjes in gelijke mate door de activiteiten zijn beïnvloed.

Vooral analyse 2 laat daarna zien dat individuele gesprekken met jongeren over de mogelijke opties omtrent eventuele vervolgopleidingen de kans aanzienlijk verhogen om alsnog verder te gaan leren. De andere activiteiten hebben echter ook een positieve invloed (zeker in analyse I). 
Tabel 2.4

Analyses (standaardfout tussen haakjes)

\begin{tabular}{|c|c|c|c|c|}
\hline \multicolumn{5}{|l|}{ Etniciteit: } \\
\hline Autochtoon & \multicolumn{2}{|c|}{ Referentie } & \multicolumn{2}{|c|}{ Referentie } \\
\hline Westerse allochtoon & 0.174 & $(0.274)$ & 0.367 & $(0.302)$ \\
\hline Niet-westerse allochtoon & $1.029^{* *}$ & $(0.147)$ & $0.977^{* *}$ & $(0.166)$ \\
\hline Afstudeercijfer & 0.076 & $(0.052)$ & 0.035 & $(0.060)$ \\
\hline Leeftijd & $-0.032^{* *}$ & $(0.010)$ & $-0.034^{* *}$ & $(0.012)$ \\
\hline Vrouw & 0.110 & $(0.152)$ & 0.118 & $(0.178)$ \\
\hline mbo-bol & -0.022 & $(0.157)$ & 0.102 & $(0.185)$ \\
\hline Opleidingsniveau (1-4) & $-0.428^{*}$ & $(0.066)$ & $-0.406^{* *}$ & $(0.076)$ \\
\hline \multicolumn{5}{|l|}{ Opleidingssector: } \\
\hline gezondheidszorg & \multicolumn{2}{|c|}{ Referentie } & \multicolumn{2}{|c|}{ Referentie } \\
\hline landbouw & -0.563 & $(0.366)$ & -0.509 & $(0.415)$ \\
\hline techniek & 0.025 & $(0.214)$ & -0.079 & $(0.246)$ \\
\hline economie & 0.075 & $(0.169)$ & -0.184 & $(0.194)$ \\
\hline gedrag en maatschappij & 0.206 & $(0.190)$ & 0.127 & $(0.218)$ \\
\hline \multicolumn{5}{|l|}{ Activiteiten van scholen: } \\
\hline School heeft brochures/website informatie & $0.618^{* *}$ & $(0.131)$ & $0.533^{* *}$ & $(0.153)$ \\
\hline Extra bijeenkomsten & $0.406^{* *}$ & $(0.135)$ & 0.169 & $(0.158)$ \\
\hline Aandacht door docenten & $0.263^{*}$ & $(0.130)$ & 0.105 & $(0.152)$ \\
\hline Individueel gesprek over toekomst & $0.377^{*}$ & $(0.155)$ & $0.362^{*}$ & $(0.178)$ \\
\hline Individueel gesprek over vervolgopleidingen & $0.835^{* *}$ & $(0.160)$ & $1.043^{* *}$ & $(0.185)$ \\
\hline Individueel gesprek over arbeidsmarkt & 0.240 & $(0.163)$ & 0.196 & $(0.179)$ \\
\hline Constante & $-1.281^{* *}$ & $(0.492)$ & $-1.591^{* *}$ & $(0.577)$ \\
\hline
\end{tabular}

Bron: Quickscan 2009, ROA. * Significant op 5\% niveau; ** Significant op 1\% niveau

Gezien het sterke effect van de etnische afkomst van de examenkandidaat is de vraag interessant of het hierbij om een algemeen effect van het totaal van schoolactiviteiten handelt, dan wel of bepaalde activiteiten jongeren van niet-westerse afkomst specifiek aanspreken. Om hier verder uitsluitsel over te geven is de bovenstaande tweede analyse (de vraag of men alsnog verder is gaan leren) afzonderlijk voor de groep niet-westerse allochtonen en voor de groep westerse allochtonenen/autochtonen uitgevoerd. De resultaten, die hier niet worden getoond, laten een tweetal interessante bevindingen toe. Ten eerste zien we dat indivuele gesprekken over mogelijke vervolgopleidingen bij beide groepen een sterk effect kennen. Echter, wat de algemene activiteiten betreft 
zien we een duidelijk verschil in de invloed van a) het organiseren van extra bijeenkomsten en b) het verspreiden van extra informatie via brochures of de eigen website. Terwijl het aanbieden van extra bijeenkomsten bij niet-westerse allochtonen de kans om 'alsnog' verder te gaan leren aanzienlijk heeft verhoogd, is het bij de groep westerse allochtonen/autochtonen juist de extra informatie via brochures of de eigen website die dit effect had. Op dit punt dient dan ook verder onderzoek plaats te vinden om in de toekomst eventueel een nog meer op maat gesneden aanpak te kunnen kiezen. 


\section{Vervolgonderwijs}

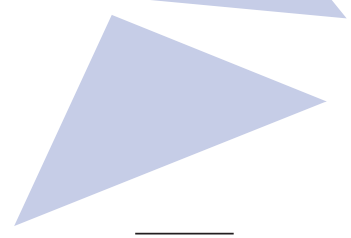

\subsection{Inleiding}

I5\% van de examenkandidaten van het voorjaar van 2009 heeft zich door activiteiten van scholen laten beïnvloeden en a) is alsnog verder gaan leren (I2\%-punt) of b) heeft zijn of haar voorkeur voor een bepaalde vervolgopleiding bijgesteld (3\%-punt). In dit hoofdstuk willen wij verder stil staan bij de groep die zich door de school heeft laten beïnvloeden. We staan echter ook stil bij de jongeren die voor een vervolgopleiding hebben geopteerd zonder daarbij door de school beïnvloed te zijn. Belangrijk is daarbij op te merken dat ook in de tweede groep jongeren te vinden zijn die misschien in het najaar van 2008 nog van plan waren om met het diploma op zak zich aan te bieden op de arbeidsmarkt. Op de vraag welke gevolgen de economische crisis voor hen persoonlijk had, zegt namelijk $29 \%$ van de respondenten dat het hen beïnvloed heeft in de keuze om wel of niet door te leren. $20 \%$ van de respondenten geeft aan dat het hen in de keuze voor een bepaalde vervolgopleiding heeft beïnvloed. Met andere woorden, het percentage jongeren dat door de crisis (zij het rechtstreeks of via de scholen) is beïnvloed in hun toekomstplannen is aanzienlijk hoger dan het percentage dat via de scholen is beïnvloed. Scholen (zowel in het mbo als in het hbo) dienen er daarom rekening mee te houden dat in het schooljaar 2009/20Io een aanzienlijk aantal jongeren aan het onderwijs deelneemt dat dit in eerste instantie niet van plan was. Navolgend staan we dan ook stil bij een drietal belangrijke vragen die betrekking hebben op de ontstane situatie: 'wie zijn de (nieuwe) vervolgstudenten?', 'wat was hun studiekeuze?' en 'is de vervolgopleiding slechts een tussenpauze?'. Echter, voordat we dat doen, vermelden we voor de volledigheid het percentage respondenten dat met een vervolgopleiding is gestart. ${ }^{2}$

Op basis van hun situatie in oktober 2009 blijkt dat $46 \%$ van de respondenten weer een opleiding aan het volgen is. De jongeren afkomstig van het mbo-bol (57\%) doen dit iets vaker dan de jongeren van het mbo-bbl (30\%). Wat de bestemming van de gediplomeerden naar opleidingsniveau in het mbo betreft, zien we conform de resultaten van hoofdstuk 2 dat de gediplomeerden van niveau I (53\%) relatief het vaakst verder leren. Op niveau 2 is het nog steeds bijna een op de twee (48\%) wat ook voor

2. De hier gepresenteerde cijfers kunnen afwijken van de cijfers zoals gepresenteerd in rapportages op basis van registergegevens. De reden hiervoor is dat de hier gepresenteerde cijfers gebaseerd zijn op een enquête en er zich daarbij eventueel responsverschillen kunnen voordoen tussen jongeren die doorstromen naar een vervolgopleiding en jongeren die dat niet doen. 
niveau $4(47 \%)$ geldt. Wellicht omdat zij geen toegang tot vervolgonderwijs op hboniveau hebben, gaan relatief weinig gediplomeerden van niveau 3 verder leren (38\%).

\subsection{Wie zijn de (nieuwe) vervolgstudenten}

De resultaten in hoofdstuk 2 hebben duidelijk aangegeven dat de scholen met hun activiteiten relatief vaker succes hebben gehad bij het stimuleren van de niet-westerse allochtone jongeren dan bij de autochtone jongeren. De vraag stelt zich dan ook of dit ook tot gevolg heeft dat de samenstelling qua etnische achtergrond van de jongeren die doorstromen naar een vervolgopleiding gaat veranderen. De tabellen 3.I en 3.2 geven daar een antwoord op. In eerste instantie laten we de samenstelling van de doorstromers naar etnische achtergrond zien, zoals deze in de reguliere meting (meetjaar 2008) onder de mbo-gediplomeerden naar voren is gekomen. ${ }^{3}$ Deze groep jongeren heeft in het schooljaar 2006/2007 het mbo-eindexamen behaald en is daarmee geconfronteerd met een redelijk goede economische situatie. Van de mbo-gediplomeerden van meting 2008 die zijn doorgestroomd binnen het mbo behoort iets minder dan $5 \%$ tot de groep westerse allochtonen, $18,7 \%$ tot de groep niet-westerse allochtone jongeren en $76,9 \%$ tot de groep autochtone jongeren. De resultaten afkomstig van de Quickscan wijken in het totaal slechts marginaal af. Zo vinden we dat de groep niet-westerse allochtonen iets groter is $(20,1 \%)$, en dat dit vooral komt doordat zij een aanzienlijk deel uitmaken van de groep die 'alsnog' verder is gaan leren (3I,6\%). Echter, omdat deze groep relatief klein is, heeft dit geen grote invloed op de totale situatie.

Tabel 3.1

Doorstroom binnen het mbo, naar etnische achtergrond (\%)

\begin{tabular}{lcccc} 
& SIS 2008 & Quickscan & $\begin{array}{c}\text { Quickscan geen } \\
\text { invloed }\end{array}$ & $\begin{array}{c}\text { Quickscan'alsnog } \\
\text { verder gaan leren }\end{array}$ \\
\hline Westerse allochtoon & 4.4 & 4.7 & 3.9 & 7.0 \\
Niet-westerse allochtoon & 18.7 & 20.1 & 16.1 & 31.6 \\
\hline Autochtoon & 76.9 & 75.2 & 80.0 & 61.4
\end{tabular}

Bron: SIS 2008/Quickscan 2009, ROA

Kijken we echter naar de doorstroom naar het hbo, dan zien we wel degelijk dat er een, ook hier echter niet in grote mate, verschuiving heeft plaatsgevonden. Reden hiervoor is wederom het feit dat niet-westerse allochtonen veel sterker door de activiteiten van de ROC's zijn beïnvloed. Vergeleken met de cijfers uit meting 2008 (II,6\% is van niet-westerse afkomst) is het niet-westerse aandeel in de hbo-instromers met $2,4 \%$ punt (of zo'n $20 \%$ ) gestegen naar $14 \%$.

3. De cijfers van meting 2008 onderscheiden zich hierbij niet van de cijfers van bijvoorbeeld meting 2007 . 
Tabel 3.2

Doorstroom naar hbo, naar etnische achtergrond (\%)

\begin{tabular}{lcccc} 
& SIS 2008 & Quickscan & $\begin{array}{c}\text { Quickscan geen } \\
\text { invloed }\end{array}$ & $\begin{array}{c}\text { Quickscan'alsnog } \\
\text { verder gaan leren }\end{array}$ \\
\hline Westerse allochtoon & 4.6 & 4.7 & 5.1 & 1.4 \\
Niet-westerse allochtoon & 11.6 & 14.0 & 12.4 & 27.2 \\
Autochtoon & 83.8 & 81.3 & 82.5 & 71.3
\end{tabular}

Bron: SIS 2008/Quickscan 2009, ROA

De activiteiten en maatregelen die scholen in het voorjaar van 2009 hebben ondernomen om jongeren te stimuleren om door te leren hebben daarmee een interessant neveneffect bereikt: Jongeren van niet-westerse afkomst stromen in 2009 relatief vaker door naar een vervolgopleiding en zeker naar een opleiding in het hbo.

Een tweede vraag die zich stelt is of er qua competentieniveau een nieuw type mbodoorstromer is. Met andere woorden, is het zo dat de gediplomeerden die alsnog verder zijn gaan leren een gemiddeld ander afstudeercijfer hebben dan de jongeren die niet beïnvloed zijn? Onze analyses in hoofdstuk 2 hebben laten zien dat de kans dat men door de activiteiten van de scholen is beïnvloed niet afhankelijk was van het gemiddeld afstudeercijfer. Echter, kijken we in wat meer detail naar de groep die doorgestroomd is, zij het binnen het mbo dan wel naar het hbo, dan vinden we wel degelijk een interessant verschil.

De groep gediplomeerden van het mbo die 'alsnog' en dankzij de invloed van de school doorgestroomd is naar het hbo heeft namelijk vaker een gemiddeld afstudeercijfer van 7 of lager dan de groep die zonder invloed van de school is doorgestroomd. Het gevaar bestaat dan ook dat er daardoor een relatief grotere groep het hbo is binnengestroomd die eventueel moeite zal kunnen krijgen met het niveau van een hbo-opleiding. Hiermee dient door hogescholen rekening te worden gehouden. Immers, de doorstroom verhogen is slechts een marginaal deel van de doelstelling. De eindstreep in het vervolgonderwijs halen is wat de maatregelen tot succes maakt. Aan deze problematiek is al eerder (zie ROA, 2009: Schoolverlaters tussen onderwijs en arbeidsmarkt 2008) aandacht besteed. Het hbo staat dan ook voor de opgave om steeds vaker, net als het mbo al langer kent, een brede variatie aan talent te bedienen. Maar waar het mbo vier opleidingsniveaus heeft en twee leerwegen is in het hbo de facto één niveau en twee leerwegen (voltijd en deeltijd, al komt de duale variant wel meer opzetten) dominant. Dit is onvoldoende om het steeds bredere palet aan talenten te bedienen en vormt op zichzelf al reden voor meer differentiatie in het hbo. De crisis laat nog een keer extra zien dat er in het hbo behoefte is aan kortlopende trajecten voor schoolverlaters van vooral het mbo-bol niveau 4 die hun niveau willen verhogen. Op zichzelf genomen bestaan deze kortlopende trajecten reeds, de zogeheten Associate Degrees. Een probleem is echter dat deze Associate Degrees nauwelijks bekend zijn onder leerlingen van het mbo. Uit de BVE-Monitor van het ROA 
blijkt dat slechts $9 \%$ van de gediplomeerde schoolverlaters van het mbo van deze korte hbo-opleidingen heeft gehoord.

Interessant is dat we bij de groep gediplomeerden die in het mbo (bijvoorbeeld van niveau 2 naar niveau 4) zijn doorgestroomd precies het tegenovergestelde vinden. Hier zien we namelijk dat de gediplomeerden die 'alsnog' en dankzij de invloed van de school zijn gaan verder leren relatief vaker een gemiddeld afstudeercijfer van 7,5 of hoger hebben dan de groep die zonder invloed van de school is doorgestroomd. Hierdoor stijgt het gemiddelde afstudeercijfer van de groep mbo gediplomeerden die binnen het mbo verder gaan leren licht. Het gevolg hiervan is dat de groep gediplomeerden die zich tijdens de crisis op de arbeidsmarkt aanbieden een gemiddeld iets lager afstudeercijfer heeft dan bijvoorbeeld de groep die in de jaren 2007 of 2008 deze keuze deed. Dit kan eventueel invloed hebben op de arbeidsmarktkansen. Immers, werkgevers die tijdens de crisis open vacatures hebben, zullen deze waarschijnlijk alleen invullen als ze een goede match vinden. Indien zij echter twijfelen aan de door schoolverlaters geboden kwaliteiten, beslissen werkgevers in onzeker tijden misschien sneller om de vacature langer onvervuld te laten. Hiermee is het gevaar aanwezig dat, ondanks het kleinere aantal nieuwe aanbieders op de arbeidsmarkt, de werkloosheid omhoog gaat.

\subsection{Studiekeuze tijdens een economische crisis}

Met een mbo niveau 4 diploma op zak is de weg open naar het hbo. Jongeren die dit wensen dienen dan een keuze tussen de verschillende opleidingen in het hoger beroepsonderwijs te maken. Voor jongeren van de lagere mbo niveaus stelt zich een vergelijkbare keuze tussen de opleidingen in het mbo. Echter, en dan vooral voor de gediplomeerden van het funderende onderwijs (de mbo niveaus I en 2) stelt zich ook de vraag of zij de vervolgopleiding binnen de leerweg (bol of bbl) vervolgen of van leerweg wisselen.

Cijfers afkomstig van het SchoolverlatersInformatieSysteem van het ROA laten zien dat het percentage gediplomeerden (examenjaar 2007 en 2008) van het mbo-bol die, indien ze voor een vervolgopleiding in het mbo kozen, van leerweg wisselden rond $30 \%$ bedroeg. Met andere woorden: bijna een op de drie mbo-bol gediplomeerden die in tijden van een redelijk sterke economie een vervolgopleiding binnen het mbo kozen, verwisselde een opleiding waar hij of zij relatief sterk met de 'neus in de boeken' zat voor een relatief sterkere 'hands on' opleiding. Kijken we echter naar de jongeren die in het voorliggende rapport centraal staan, de examenkandidaten van het schooljaar 2009, dan zien we dat dit percentage slechts $15 \%$ is. De economische crisis heeft duidelijk haar sporen achtergelaten. Bedrijven die in slecht economisch weer terecht zijn gekomen bieden minder snel leerplaatsen aan. Daarom is het aanzienlijk moeilijker geworden voor jongeren van het mbo-bol om de overstap te maken naar het mbo-bbl. Gelukkig kunnen we vaststellen dat dit niet tot een situatie geleid heeft 
waarin een overgroot deel van de potentiële 'overstappers' voor het stopzetten van de opleiding heeft gekozen. Vooruitlopend op hoofdstuk 5 dienen we ter volledigheid wel te vermelden dat onder de gediplomeerden van het mbo-bol die op het moment van de enquête noch werkzaam zijn noch met een opleiding bezig zijn $6 \%$ meldt dat het 'niet vinden van een bbl-leerplaats' de reden is waarom ze geen vervolgopleiding volgen (onder de jongeren afkomstig van het mbo-bbl is dit zelfs $\mathrm{I} 4 \%^{4}$ ). Verder geldt dat het percentage hoger ligt bij de gediplomeerden van mbo techniek. Reden hiervoor is dat precies in deze sector het mbo-bbl een belangrijke rol vervult. Verder geeft 36\% van de mbo-bol gediplomeerden die noch werkzaam zijn noch een vervolgopleiding volgen als reden voor het niet volgen van een vervolgopleiding aan dat ze liever werken dan naar school gaan. Aangezien ook een deel van deze jongeren eventueel door het beschikbaar stellen van een betaalde bbl-leerplaats geholpen zou kunnen worden, dienen we te concluderen dat de afname in de zomer van 2009 wat het aanbod aan bbl-leerplaatsen betreft een reden kan vormen waarom een deel van de examenkandidaten niet met een vervolgopleiding is gestart.

Wel dienen we er tegelijkertijd mee rekening te houden dat het vervolgen van de opleiding in het mbo-bol eventueel door een aanzienlijk percentage jongeren als een gedwongen keuze gezien wordt. Ondanks het feit dat we in paragraaf 3.4 zullen laten zien dat jongeren de vervolgopleiding niet slechts als een tussenpauze zien, dienen we er mee rekening te houden dat deze gedwongen keuze in de nabije toekomst nadelige consequenties kan hebben. Het gevaar kan liggen in een verminderde motivatie van jongeren die gedwongen met de 'neus in de boeken' gedrukt worden of in het wegvallen van het testen van de geschiktheid van jongeren voor een bepaalde (vervolg)opleiding door bedrijven die bbl-plaatsen aanbieden. Jongeren stimuleren om door te leren is daarom slechts het begin, deze jongeren ook te motiveren om de vervolgopleiding met succes af te ronden dient de echte doelstelling te zijn (zie ook tekstbox 3.I). Daarnaast dient zeker ook nagestreefd te worden dat in de toekomst verdere activiteiten ontwikkeld worden om de opleidingscapaciteit van het bbl in stand te houden in tijden van economische malaise. Een anticyclische subsidie aan bedrijven zou hierbij wellicht kunnen helpen: in tijden van economische bloei de subsidie verlagen om in tijden van economische malaise de subsidie te verhogen zal een stabieler aanbod van bbl-plaatsen kunnen garanderen. Daardoor zal de keuze tussen 'neus in de boeken' en 'hands on' ook in tijden van crisis een vrijwillige keuze kunnen zijn. Om in tijden van terugvallende overheidsinkomsten overigens lange discussies te voorkomen, dient deze anticyclische subsidie voor een langere periode vastgesteld te worden.

4. In tegenstelling tot de gediplomeerden van het mbo-bol die gezien het wegvallende alternatief (mbobbl) voor een vervolg in de eigen leerweg kozen, zien we bij de gediplomeerden van het mbo-bbl eerder een keuze voor het verlaten van het onderwijs dan voor een wissel naar het mbo-bol. 


\section{Tekstbox 3.1}

Hoe vergaat het gediplomeerde mbo'ers overigens in vervolgonderwijs?

Stimuleren dat mbo-gediplomeerden in tijden van economische malaise hun arbeidsmarktintrede uitstellen door verder te studeren is één ding, zorgen dat zij hun vervolgopleiding niet voortijdig beëindigen is een ander ding. In het ROA-rapport Schoolverlaters tussen onderwijs en arbeidsmarkt 2008 is gekeken naar het percentage gediplomeerde doorstromers naar vervolgonderwijs dat op het moment van enquêteren (ongeveer anderhalf jaar na het behalen van het diploma) de vervolgopleiding weer heeft verlaten of van studie is gewisseld. Van de verder lerende gediplomeerden mbo-bol geeft 10\% aan gestopt te zijn met de aanvankelijk gekozen vervolgopleiding. Bij het mbo-bbl is dit $4 \%$. Wellicht nog belangrijker dan het percentage 'afhakers' vlak na aanvang van de vervolgstudie is het percentage van hen dat ook niet aan een andere studie begonnen is. Met andere woorden welk deel van deze uitvallers zijn studiewisselaars en welk deel heeft op het enquêtemoment echt het onderwijs verlaten? Het gaat dus niet alleen om de hoogte van de bruto uitval maar met name om de netto uitval. Welnu, van de $10 \%$ met de vervolgopleiding gestopte gediplomeerden mbo-bol is gemiddeld 4\%-punt studiewisselaar, dat wil zeggen iemand die nog niet uit het vervolgonderwijs verdwijnt maar in eerste instantie een verkeerde studiekeuze lijkt te hebben gemaakt. Van de 4\% met de vervolgopleiding gestopte gediplomeerden mbo-bbl is gemiddeld 1\%-punt studiewisselaar.

Figuur T3.1 laat zien dat mbo-gediplomeerden die doorstromen naar vervolgonderwijs in de afgelopen jaren steeds minder genegen zijn om voortijdig met de vervolgopleiding te stoppen. Dit verschijnsel treedt versterkt op tijdens de economische crisisperiode van 2001 - 2005.

\section{Figuur T3.1}

Aandeel mbo-doorstudeerders dat voortijdig stopt met de vervolgopleiding (\%)

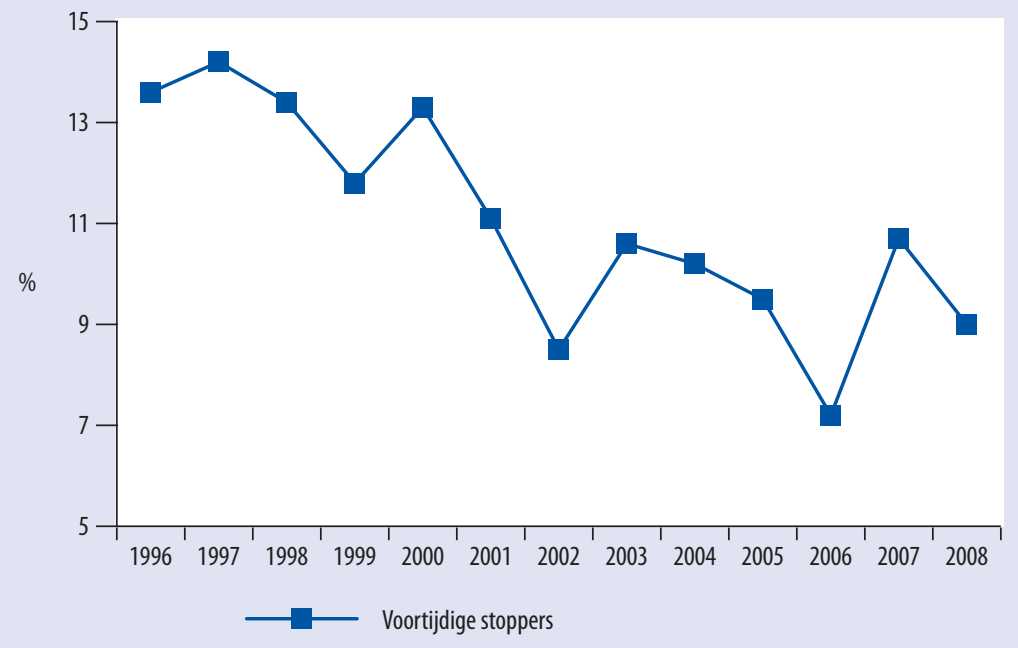


Naast de keuze voor een bepaalde leerweg is de keuze voor een bepaalde opleidingsrichting van groot belang. Voor de voorliggende rapportage is daarbij vooral de vraag van belang of men aanvankelijk van plan was om een andere opleiding te gaan volgen maar door de crisis (zij het rechtstreeks of via de activiteiten van de scholen) van keuze is veranderd. Tabel 3.3 laat zien dat van de gediplomeerden die een vervolgopleiding zijn gaan volgen $15 \%$ in eerste instantie een andere opleiding in gedachte had. Opvallend is dat er zich nogal verschillen voordoen tussen de gediplomeerden van de vijf onderscheiden opleidingssectoren in het mbo. Veranderde meer dan een op de vijf gediplomeerden in de sector landbouw van mening, is dit bij de sectoren techniek ( $16 \%$ ) en economie ( $17 \%$ ) rond een op de zes. Het laagste percentage 'wisselaars' zien we bij de sector gezondheidszorg en de sector gedrag en maatschappij. In hoofdstuk 2 hebben we al laten zien dat er zeker tussen de twee laatstgenoemde sectoren en de drie andere sectoren verschillen zijn wat de conjunctuurgevoeligheid van de arbeidsmarkt betreft. De resultaten in tabel 3.3 geven dan ook, al is het slechts een begin, een indicatie dat in tijden van economische malaise jongeren proberen conjunctuurgevoelige opleidingen te mijden. Een vergelijkbaar resultaat is al eerder in de rapportage Schoolverlaters tussen onderwijs en arbeidsmarkt 2008' (ROA, 2009) gepresenteerd, maar vraagt zeker om verdergaand onderzoek.

Tabel 3.3

Was van plan om aanvankelijk een andere opleiding te gaan volgen, per sector (\%)

\begin{tabular}{ccccccc} 
& Landbouw & Techniek & Economie & Gezondheidszorg & Gedrag en maatschappij & mbo-totaal \\
\hline Ja & 21 & 16 & 17 & 12 & 13 & 15 \\
Bron: Quickscan 2009, ROA & & & &
\end{tabular}

\subsection{Vervolgopleiding als tussenpauze}

De laatste vraag waar we in dit hoofdstuk op in willen gaan is de vraag of men van plan is om met de vervolgopleiding te stoppen indien men een betaalde baan aangeboden krijgt. Met andere woorden, wordt de vervolgopleiding als tussenpauze gezien tot men een betaalde functie vindt? Gemiddeld geeft slechts $4 \%$ van de jongeren aan dat ze bij een dergelijk aanbod met de vervolgopleiding zullen stoppen. Circa $23 \%$ weet niet wat ze zouden doen en $73 \%$ zegt dat ze niet zullen stoppen. Hierbij doen zich geen echt grote verschillen voor tussen jongeren afkomstig van de vier verschillende onderwijsniveaus. Wel zijn er verschillen te vinden tussen jongeren afkomstig van de verschillende onderwijssectoren. Tabel 3.4 laat zien dat vooral jongeren uit de sector landbouw nogal twijfelen of ze in geval van een arbeidsmarktaanbod zullen stoppen met hun vervolgstudie. 'Slechts' 63\% van hen is niet van plan te stoppen. Dit is aanzienlijk lager dan bij de jongeren uit de andere sectoren en zeker uit de sector gezondheidszorg, waar $80 \%$ niet zal stoppen. Hierbij kan eventueel meespelen dat zij relatief vaker hun studiekeuze in verband met de economische crisis aangepast hebben. De vervolgopleiding die zij op het moment van de enquête volgen, sluit 
dan misschien ook iets minder goed bij de vooropleiding aan dan bij jongeren uit bijvoorbeeld de sector gezondheidszorg. Daardoor bestaat het gevaar dat de opleiding minder goed aan de verwachtingen voldoet. Een slechte match tussen de werkelijkheid en de verwachting is een belangrijke reden om met een opleiding te stoppen. Zo stopte rond $20 \%$ van de voortijdige schoolverlaters in het schooljaar 2005/2006 met de opleiding omdat de opleiding niet aan de verwachtingen voldeed of omdat ze van plan waren om van opleiding te wisselen (ROA, 2009, Zonder diploma: Aanleiding, Kansen en Toekomstintenties).

Tabel 3.4

Zou je stoppen als je een baan aangeboden kreeg (\%)

\begin{tabular}{lcccccc} 
& Landbouw & Techniek & Economie & $\begin{array}{c}\text { Gezond- } \\
\text { heidszorg }\end{array}$ & $\begin{array}{c}\text { Gedrag en } \\
\text { maatschappij }\end{array}$ & mbo-totaal \\
\hline Ja & 4 & 2 & 6 & 2 & 2 & 4 \\
Weet ik niet & 32 & 26 & 22 & 19 & 26 & 23 \\
Nee & 63 & 72 & 73 & 80 & 72 & 73
\end{tabular}

Bron: Quickscan 2009, ROA

Interessant is verder dat er wat deze vraag betreft geen echt grote verschillen bestaan tussen enerzijds jongeren die eerder aangaven dat ze door de schoolactiviteiten beïnvloed zijn (en daarom alsnog verder gingen leren) en anderzijds jongeren die in hun keuze voor een vervolgopleiding niet door de schoolactiviteiten zijn beïnvloed. De resultaten laten zien dat van de jongeren die beïnvloed zijn zelfs een iets kleiner deel zegt met de vervolgopleiding te stoppen als ze een betaalde baan aangeboden krijgen dan van de groep die zegt niet beïnvloed te zijn. Zoals reeds is vermeld zijn het geen grote verschillen, maar toont het wel aan dat de eerstgenoemde groep op zijn minst net zo overtuigd is van de gemaakte keuze als de tweede groep. 


\section{Kansen op de arbeidsmarkt}

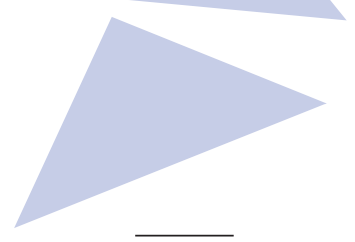

\subsection{Inleiding}

Wat zijn de kansen van de recent gediplomeerden van het mbo op de arbeidsmarkt ten tijde van een economische crisis? Vinden ze (snel) werk en biedt dit werk ook zekerheid? In eerste instantie valt of staat een succesvolle intrede op de arbeidsmarkt met het al dan niet vinden van een baan. De feitelijke werkzaamheden, verantwoordelijkheden en de inhoud van de functie bepalen daarnaast in hoeverre iemand de mogelijkheid heeft om zijn of haar kennis en vaardigheden te benutten. Tot slot bepalen de inhoud en het niveau van het werk de financiële vergoeding die hier tegenover staat. Beginnende deelnemers op de arbeidsmarkt komen vaak in startfuncties terecht. Echter, ook voor individuen in deze functies geldt dat de kwaliteit van het werk toeneemt naarmate de gevonden baan beter aansluit op de gevolgde opleiding.

In dit hoofdstuk staan we stil bij de gediplomeerden van het schooljaar 2008/2009 die zich op de arbeidsmarkt hebben aangeboden. Onder aanbieders verstaan we zowel de jongeren die werkzaam zijn op de arbeidsmarkt als degenen die actief op zoek zijn naar werk. We staan achtereenvolgens stil bij de 'kans op werk', de 'zekerheid van het gevonden werk', de 'aansluiting tussen de opleiding en het gevonden werk' en de 'beloning'.

\subsection{Kans op werk}

De gediplomeerden van het schooljaar 2008/2009 waren zich er zeker van bewust dat de arbeidsmarktomstandigheden die zij aantroffen aanzienlijk moeilijker waren dan wat gediplomeerden nog maar een jaar eerder aantroffen. Het is dan ook niet opvallend dat het percentage werklozen onder de aanbieders met $13,6 \%$ relatief hoog uitviel. De nieuwe aanbieders deden het daarbij overigens niet echt slechter dan de jongeren die zich al eerder op de arbeidsmarkt hadden aangeboden. Immers, de algemene jeugdwerkloosheid in oktober-december 2009 was met $12,4 \%$ slechts een fractie lager. ${ }^{5}$ Het werkloosheidspercentage varieert daarbij duidelijk per provincie (zie figuur 4.I). Zo kennen de provincies Gelderland en Noord-Brabant een werkloosheid onder de IO\%, en ligt de werkloosheid in Zeeland, Utrecht, Overijssel, Groningen en Friesland tussen de IO\% en I5\%. Werkloosheidspercentages boven de $15 \%$ komen voor in Limburg, Noord-Holland, Zuid-Holland, Flevoland en Drenthe. Een verkla-

5. Seizoengecorrigeerde werkloosheid van $15-25$ jarigen in de periode oktober-december 2009, Bron: CBS, Statline. 
ring voor de variatie in werkloosheidspercentages tussen provincies zou kunnen liggen in het verschil in keuze tussen verder gaan leren en zich aanbieden op de arbeidsmarkt. Echter, nadere analyses laten zien dat er geen verband te vinden is tussen het percentage dat zich in een provincie aanbiedt op de arbeidsmarkt en het percentage werklozen. Met andere woorden, de variatie in werkloosheid tussen provincies wordt vooral bepaald door verschillen tussen provincies met betrekking tot de mate waarin de vraag naar jongeren is afgenomen.

\section{Figuur 4.1}

Werkloosheid naar woonprovincie (\%)

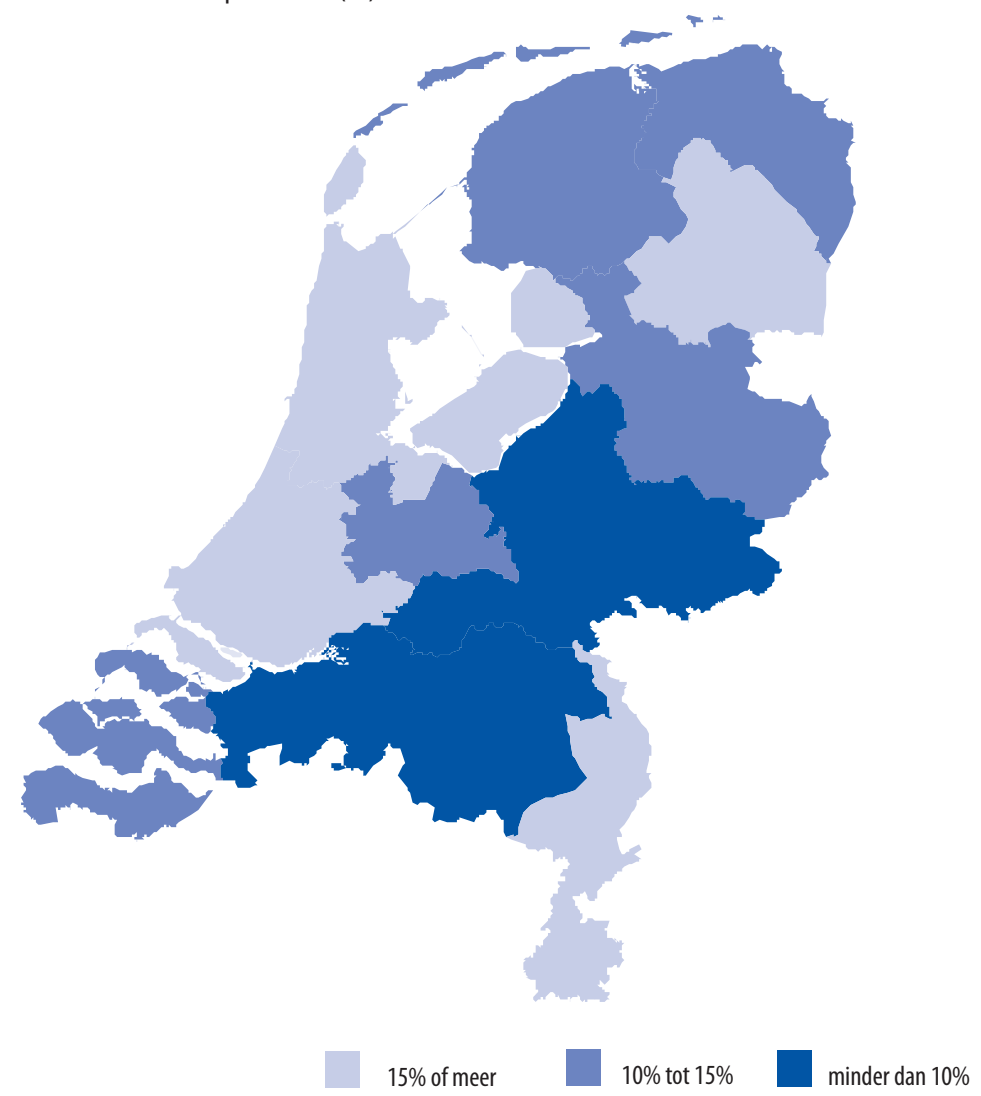

Bron: Quickscan 2009, ROA

Naast een regionaal effect kent de werkloosheid vooral een sterk effect van de gevolgde leerweg (mbo-bol en mbo-bbl) en van het niveau van de gevolgde opleiding (zie figuur 4.2). De gediplomeerden van het mbo-bbl niveau $3 / 4$ kennen kort na het behalen van het diploma met 3,4\% een bijna vijf keer zo laag werkloosheidspercentage als hun collega's die op hetzelfde niveau een opleiding in het mbo-bol hebben gevolgd (I8,7\%). Ook de gediplomeerden van het mbo-bbl niveau I/2 doen het met een werkloosheid 
van $9,8 \%$ aanzienlijk beter dan hun collega's met een diploma van het mbo-bol niveau I/2 (32,9\%). De start op de arbeidsmarkt blijkt daarmee voor de gediplomeerden van het mbo-bbl soepeler te verlopen dan voor de gediplomeerden van het mbo-bol. Dit resultaat hoeft daarbij niet noodzakelijkerwijs een gevolg van de economische crisis te zijn. Onderzoek onder eerdere cohorten van mbo-gediplomeerden laat zien dat ook in economisch sterke jaren (zoals het jaar 2007) de werkloosheid onder recent gediplomeerden van het mbo-bol aanzienlijk hoger ligt dan onder de gediplomeerden van het mbo-bbl. De hier gepresenteerde werkloosheidscijfers van oktober/november 2009 laten daarnaast duidelijk het belang van het opleidingsniveau zien als indicator voor een succesvolle arbeidsmarktstart. Nadere analyses bevestigen ook de waarde van het behalen van een startkwalificatie (d.w.z. een diploma op mbo niveau 2). Jongeren die de arbeidsmarkt met een mbo-diploma op niveau I betreden hebben een significant hogere kans op werkloosheid dan hun collega's met een diploma op niveau 2. Ook hier geldt echter dat dit niet per se een gevolg van de economische crisis is, maar eerder een structureel effect dat al eerder in rapportages (zie bijvoorbeeld ROA, 2009: Zonder diploma: Aanleiding, Kansen en Toekomstintenties) naar voren kwam.

\section{Figuur 4.2}

Werkloosheid na gevolgde opleiding (\%)

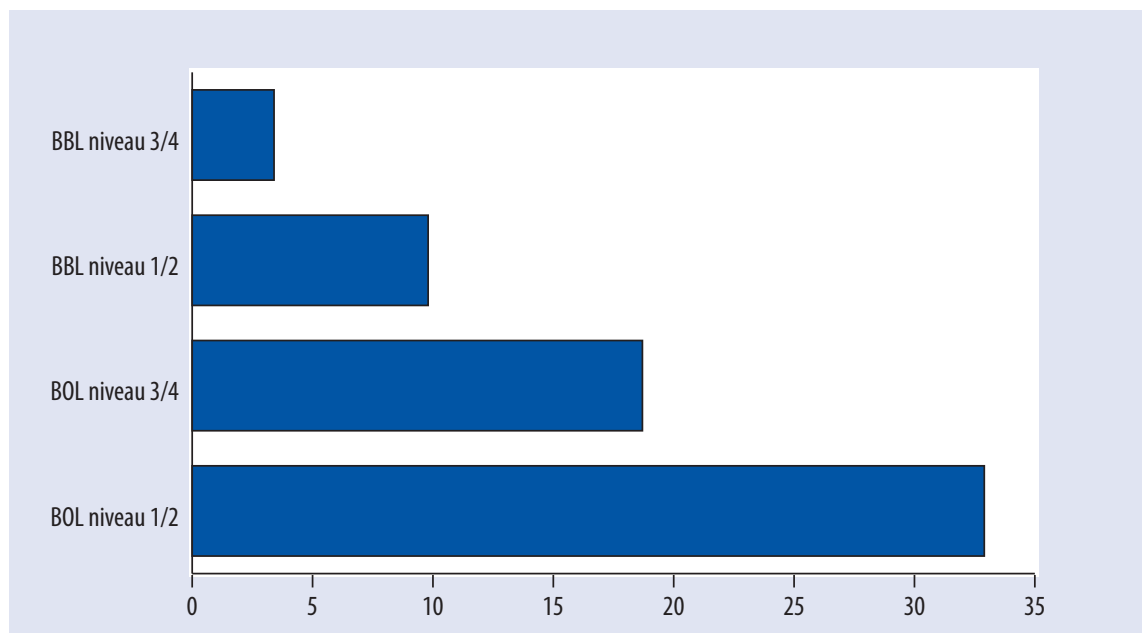

Bron: Quickscan 2009, ROA

Behalve naar opleidingstype en opleidingsniveau varieert de werkloosheid ook naar de opleidingssector die men in het mbo heeft gevolgd. De werkloosheid is met $9 \%$ het laagst onder gediplomeerden mbo gezondheidszorg en met $19 \%$ het hoogst onder gediplomeerden mbo economie. Bij de overige opleidingssectoren bedraagt de werkloosheid II\% (mbo landbouw), I2\% (mbo gedrag \& maatschappij) en I3\% (mbo techniek). 
Een sterk vergelijkbaar beeld komt ook naar voren als we kijken naar de zoekduur tot de eerste betaalde functie die, gezien de korte tijdsperiode tussen het behalen van het diploma en het enquêtemoment, vaak overeenkomt met de huidige functie. Gemiddeld was de zoekduur met o,3 maanden van deze 'succesvolle' groep minimaal, variërend van minder dan een werkweek (bbl niveau 3/4) tot zo'n 3 weken (bol niveau $\mathrm{I} / 2)$.

De gemiddelde zoekduur voor deze 'succesvolle' groep varieert behalve naar opleidingstype en -niveau ook naar opleidingssector. De gediplomeerden van de mbosector landbouw vonden hun eerste baan binnen een werkweek terwijl de gediplomeerden van de mbo-sector economie hiervoor gemiddeld 2 weken nodig hadden. Dit is in lijn met de eerder gepresenteerde bevinding dat de economische situatie voor de gediplomeerden van de mbo-sector economie het minst gunstig is. Tekstbox 4.I laat zien welke andere inspanningen de 'succesvolle' groep heeft gedaan om aan de huidige functie te komen en welke lering de 'niet succesvolle' jongeren hieruit kunnen trekken.

\section{Tekstbox 4.1}

Solliciteren tijdens een economische crisis

In tijden van een economische crisis liggen de beschikbare banen niet voor het oprappen. De vraag is dan ook welke inspanningen jongeren dienen te plegen om een functie te bemachtigen. Tabel T4.1 laat zien dat van de jongeren die op het moment van de enquête (oktober 2009) een betaalde werkzaamheid hebben, rond de driekwart deze met minder dan 3 sollicitatiebrieven heeft gevonden en 8 van de 10 ook minder dan 3 sollicitatiegesprekken nodig had. $52 \%$ zegt zelfs dat hiervoor geen enkele sollicitatiebrief nodig was, en $18 \%$ was zelfs zonder sollicitatiegesprek aangenomen. Ter vergelijking, van de gediplomeerden die op het moment van de enquête noch werkzaam noch met een vervolgopleiding bezig zijn, heeft $62 \%$ al meer dan 3 sollicitatiebrieven verstuurd ( $43 \%$ zelfs al meer dan 5 ). Echter, het aantal sollicitatiegesprekken loopt daarbij niet parallel met het aantal brieven op. Van de niet-succesvolle schrijvers is namelijk slechts $14 \%$ al meer dan 3 keer voor een sollicitatiegesprek uitgenodigd.

Tabel T4.1

Aantal sollicitatiebrieven/sollicitatiegesprekken tot vinden eerste baan (\%)

\begin{tabular}{lcc}
\hline & $<3$ brieven & $<3$ gesprekken \\
\hline bol $1 / 2$ & 77 & 85 \\
bol $3 / 4$ & 71 & 81 \\
bbl $1 / 2$ & 81 & 75 \\
bbl 3/4 & 84 & 81 \\
Totaal & 78 & 80 \\
Bron: Quickscan 2009, ROA & &
\end{tabular}




\section{Tekstbox 4.1 (vervolg)}

Solliciteren tijdens een economische crisis

Het resultaat dat een deel van de succesvolle sollicitanten zonder sollicitatiebriefen deels zelfs zonder sollicitatiegesprek de huidige baan heeft gevonden, spoort daarbij met een aantal andere resultaten van de enquête: $17 \%$ vond de huidige baan namelijk via een eerdere stage en $16 \%$ via familie/vrienden of kennissen. Stage is bij de bol niveau $3 / 4$ gediplomeerden (32\%) daarbij duidelijk van bovengemiddeld belang, terwijl familie/vrienden en kennissen bij de lagere niveaus een iets grotere rol spelen dan bij de hogere niveaus. Naast deze twee vindkanalen blijken voor de werkende mbo-gediplomeerden vooral een tweetal andere kanalen in het algemeen goed te werken. Zo heeft 18\% de huidige baan via een open sollicitatie gevonden en 15\% reageerde op een advertentie. Een op de 10 werkende mbo-gediplomeerden geeft verder aan de huidige functie via een bemiddelingsbureau gevonden te hebben: bij $3 \%$ was dit het UWV en bij 7\% een commercieel bemiddelingsbureau. Het UWV speelt bij de gediplomeerden van het mbo-bbl (4\%) een iets belangrijkere rol dan bij de gediplomeerden van het mbo-bol (1\%). Hier kan meespelen dat de gediplomeerden van het mbo-bbl a) door hun uitgebreidere werkervaring tijdens de opleiding en hun gemiddeld aanzienlijk hogere leeftijd de weg naar het UWV eenvoudiger kunnen vinden en eventueel hierbij ook door hun oude werkgever (het leerlingbedriff) ondersteund worden.

Het overgrote deel van de niet-succesvolle sollicitanten blijkt overigens wel bereidwillig om te werken. De resultaten laten namelijk zien dat $80 \%$ van deze jongeren nog geen enkele aangeboden baan heeft afgewezen. Als individueel belangrijkste reden om een aanbod af te wijzen lijkt hier vooral de reisafstand naar voren te komen. Betekent dit dat deze groep jongeren niet bereid zijn om een eventueel langere reisafstand te accepteren. $0 \mathrm{~m}$ hier achter te komen is aan de jongeren dan ook gevraagd om aan te geven hoe lang de reistijd 's ochtends naar het werk maximaal mag zijn. Aangezien tegelijkertijd aan de werkende mbo-gediplomeerden de vraag gesteld is hoe lang hun reistijd 's ochtends van huis naar werk is, biedt dit een interessant inzicht in de mobiliteit van werkenden en werkzoekenden. Tabel T4.2 laat zien of de werkzoekenden bereid zijn om relatief gezien in de ochtend langer onderweg te zijn naar het werk dan de reistijd van de werkende mbo-gediplomeerden in werkelijkheid is.

Tabel T4.2

Maximaal gewenste reistijd bij werkzoekenden en actuele reistijd bij de werkende mbo-gediplomeerden (\%)

\begin{tabular}{lcc}
\hline & Werkzoekenden & Werkenden \\
\hline$<30$ minuten & 41 & 75 \\
$30-60$ minuten & 46 & 22 \\
$>60$ minuten & 13 & 4 \\
\hline
\end{tabular}

Bron: Quickscan 2009, ROA

Naast de gevolgde leerweg (bol of bbl), het niveau van de opleiding en de sector speelt ook de etniciteit een belangrijke rol. Met een werkloosheid van 30\% blijken de gemiddeld lager opgeleide niet-westerse allochtone gediplomeerden een beduidend kleinere kans op werk te hebben dan de westerse allochtonen (2I\% werkloos) of de autochtonen (II\% werkloos). Allochtonen zijn daarmee aanzienlijk vaker werkloos. Voordat we dit echter daadwerkelijk kunnen concluderen, is het noodzakelijk om analytisch na te gaan of dit effect niet tot stand komt door de combinatie van een tweetal factoren: allochtonen zijn relatief oververtegenwoordigd in het mbo-bol en allochtonen zijn relatief oververtegenwoordigd in de lagere opleidingsniveaus. Om de verschillen zo zuiver mogelijk te presenteren is daarom in additioneel uitgevoerde analyses nagegaan in hoeverre de verschillen met betrekking tot de kans op werk overeind blijven indien voor deze achtergrondkenmerken gecontroleerd wordt. Tabel 
4.I presenteert de resultaten van een drietal analyses, namelijk de kans dat men zich op de arbeidsmarkt aanbiedt, de kans dat men werk heeft gevonden en de kans dat men een vaste aanstelling heeft. Naast de kans op werk bieden de resultaten daarmee ook een eerste inzicht in de zekerheid van het gevonden werk. Om de analyses van de verschillen zo zuiver mogelijk te houden, is in alle analyses onder andere gecontroleerd voor eventuele verschillen ten aanzien van het gevolgde opleidingstype (bol versus bbl), het gevolgde opleidingsniveau, de gevolgde opleidingssector, het behaalde examencijfer, de leeftijd en het geslacht.

Tabel 4.1

Kans op werk direct na diploma

$\begin{array}{lcc} & \text { Regressie coëfficiënten } \\ \text { Aanbieden op } & \text { Werkzaam } & \text { Vaste baan } \\ \text { arbeidsmarkt } & \text { W }\end{array}$

Autochtonen (referentie)

\section{- Westerse allochtonen}

- Niet-westerse allochtonen

$x$ Verschil niet significant

Bron: Quickscan 2009, ROA

In vergelijking met autochtonen bieden niet-westerse allochtone gediplomeerden in 2008/2009 zich niet alleen minder vaak aan op de arbeidsmarkt, maar doen zij dit ook (evenals westerse allochtonen) met minder succes. Ook als zij werk vinden, hebben niet-westerse allochtonen een kleinere kans op een vaste aanstelling dan westerse allochtonen en autochtonen.

De vraag is of de bovenvermelde resultaten, de minder succesvolle transitie naar de arbeidsmarkt voor (niet-)westerse allochtonen, een direct gevolg zijn van de economische crisis. Om deze vraag te beantwoorden zijn, op basis van het SchoolverlatersInformatieSysteem van het ROA, additionele analyses uitgevoerd naar de arbeidsmarktsituatie van mbo-bol gediplomeerden in goede en slechte economische tijden. In tegenstelling tot de hierboven vermelde resultaten heeft de arbeidsmarktsituatie daarbij betrekking op de situatie circa I,5 jaar na het behalen van het diploma. In de analyses zijn de economisch goede tijden geoperationaliseerd als de meetjaren $1996 \mathrm{t} / \mathrm{m} 2000$ en $2006 \mathrm{t} / \mathrm{m}$ 2008, en de economisch slechte tijden als de meetjaren $200 \mathrm{t} t / \mathrm{m}$ 2005. De resultaten van de analyses met betrekking tot eventuele verschillen naar etniciteit staan in tabel 4.2 samengevat.

Zowel in goede tijden als in slechte tijden zijn allochtonen minder vaak beschikbaar voor de arbeidsmarkt. Echter, vergeleken met autochtonen trekken allochtonen zich in slechte tijden versterkt terug van de arbeidsmarkt. Dit effect speelt nog sterker bij niet-westerse allochtonen dan bij westerse allochtonen. Bij de gediplomeerden die zich op de arbeidsmarkt aanbieden blijkt dat niet-westerse allochtonen vergeleken met autochtonen zowel in goede tijden als in slechte tijden (westerse allochtonen 
alleen in slechte tijden) een kleinere kans op werk hebben. Het verschil in baankans tussen autochtonen en allochtonen is groter in slechte tijden dan in goede tijden. Ook als ze werk hebben, hebben niet-westerse allochtonen minder kans op een vaste baan dan autochtonen (westerse allochtonen alleen in slechte tijden).

Tabel 4.2

Kans op werk: Goede tijden, slechte tijden

$\begin{array}{lcc} & \text { Regressie coëfficiënten } \\ \text { Aanbieden op } & \text { Werkzaam } & \text { Vaste baan } \\ \text { arbeidsmarkt } & \end{array}$

\section{Goede tijden}

Autochtonen (referentie)

- Westerse allochtonen

Niet-westerse allochtonen

$\begin{array}{ccc}-0,605 & x & x \\ -1,110 & -0,868 & -0,723\end{array}$

\section{Slechte tijden}

Autochtonen (referentie)

- Westerse allochtonen

$-0,162$

$-0,366$

$-0,345$

- Niet-westerse allochtonen

$-0,750$

$-1,158$

$-0,444$

$x$ Verschil niet significant

Bron: SIS 1996-2008, ROA

Samenvattend kunnen we dan ook vaststellen dat de neergaande economische cyclus in 2009 directe negatieve gevolgen voor de gediplomeerden had en een toename van de jeugdwerkloosheid met zich meebracht, omdat het voor werkgevers gemakkelijker is om geen schoolverlaters aan te nemen dan om zittend personeel te ontslaan. De vraag is of de conjunctuur bij het betreden van de arbeidsmarkt ook gevolgen heeft voor de latere loopbaan. Deze vraag is van belang met het oog op de gediplomeerden van het schooljaar 2008/2009, maar zeker ook met het oog op de jongeren die op het moment van schrijven van deze rapportage (maart 2009) kort voor hun eindexamen in het middelbaar onderwijs staan. Met andere woorden, ondervinden deze jongeren slechts op korte termijn problemen bij het vinden van werk of zijn de gevolgen van de instroom op de arbeidsmarkt in een slechte conjunctuur van blijvende aard? In een eerder gepubliceerd rapport (ROA, 2009: Schoolverlaters tussen onderwijs en arbeidsmarkt 2008) is op deze vraag uitgebreid ingegaan op basis van de arbeidsmarktsituatie in het begin van de jaren 2000 van het cohort schoolverlaters dat de arbeidsmarkt instroomde in de jaren I98I-I984. Evenals het huidige cohort gediplomeerden werd dit cohort geconfronteerd met een sterk stijgende jeugdwerkloosheid. Op basis van een breed pallet van analyses kon geconcludeerd worden dat schoolverlaters die het hardst getroffen worden door een stijgende werkloosheid, op de langere termijn geen nadelige gevolgen ondervinden voor hun employability: ze zijn niet vaker werkloos en ook niet vaker inactief. Ook voor het behaalde beroepsniveau konden geen gevolgen van de economische crisis van begin jaren tachtig gevonden worden. Ondanks dat de 
recente gediplomeerden een uitermate moeilijke start kennen op de arbeidsmarkt, hoeven we dan ook niet direct te vrezen voor een verloren generatie.

\subsection{Huidige functie}

Werk vinden blijkt een eerste moeilijke stap te zijn voor de gediplomeerden van het schooljaar 2008/2009. De volgende vraag doet zich dan ook voor: indien ze werk hebben gevonden, wat voor soort werk dit is dan? In wat volgt staan we stil bij een aantal aspecten van het werk dat de jongeren gevonden hebben. We doen dit in eerste instantie aan de hand van de vraag of de jongeren werkzekerheid hebben gevonden, en of de huidige functie qua richting en niveau goed aansluit bij de gevolgde opleiding. Werkzekerheid is zeker in tijden van economische onzekerheden een belangrijk aspect van het werk. Dit geldt in het bijzonder voor jongeren die nog geen gevestigde plaats op de arbeidsmarkt hebben verworven en vaak als eerste worden ontslagen indien het bedrijf waarvoor zij werken het moeilijk krijgt. Een vaste aanstelling kan hiertegen dan ook bescherming bieden. Eerder hebben we al vastgesteld dat de werkzekerheid zowel in goede als in slechte economische tijden lager ligt voor niet-westerse allochtonen met een mbo-diploma. Tabel 4.3 laat nu in eerste instantie zien dat gemiddeld zo'n 2 op de 3 werkende gediplomeerden van het schooljaar 2008/2009 wel een vaste aanstelling hebben. Ter vergelijking vermelden we in tabel 4.3 ook de cijfers voor het mbo-totaal zoals deze in meting 2008 zijn vastgesteld. Belangrijk is daarbij dat de cijfers uit meting 2008 I,5 jaar na het behalen van het diploma zijn gemeten en niet slechts enkele maanden na het behalen van het diploma. Ondanks dit verschil zien we dat de werkzekerheid van recent gediplomeerden niet achterloopt op de werkzekerheid die eerdere cohorten hadden. Opvallend is wel het verschil dat zich tussen de gediplomeerden van het mbo-bol en het mbo-bbl voordoet. Laatstgenoemde groep kent gemiddeld een aanzienlijk hogere werkzekerheid wat een gevolg kan zijn van hun gemiddeld hogere leeftijd en werkervaring. Nadere analyses laten verder qua werkzekerheid geen verschillen naar gevolgde opleidingssector zien (zie tabel 4.4).

Tabel 4.3

Kenmerken van de huidige functie naar opleidingstype en -niveau in het mbo (\%)

\begin{tabular}{lccc} 
& Vaste aanstelling & Eigen domein & Eigen niveau \\
\hline bol $1 / 2$ & & & \\
\hline bol $3 / 4$ & 49 & 82 & 58 \\
\hline bbl $1 / 2$ & 43 & 75 & 64 \\
\hline bbl $3 / 4$ & 71 & 57 & 74 \\
\hline Totaal & 82 & 81 & 73 \\
& 64 & 70 & 75 \\
\hline SIS 2008 mbo totaal & & & \\
Bron: SIS 2008 / Quickscan 2009, ROA & 67 & 70 &
\end{tabular}


Naast de gevonden werkzekerheid laten tabellen 4.3 en 4.4 nog een tweetal functiekenmerken zien, namelijk de vraag of a) de huidige functie goed bij de gevolgde opleidingsrichting en b) bij het gevolgde opleidingsniveau aansluit. Een goede aansluiting is daarbij van belang aangezien de inhoud en het niveau van het werk in sterke mate bepalend is voor de mate waarin de gediplomeerden hun kennis en vaardigheden kunnen benutten. Starten in een functie die qua richting dan wel niveau niet goed aansluit kan dan ook snel gepaard gaan met een vertraagde opbouw van relevante arbeidsmarktervaring en kan gevolgen hebben voor het verdere verloop van de loopbaan. De resultaten in tabel 4.3 laten zien dat ook wat deze functiekenmerken betreft de situaties van de werkende mbo-gediplomeerden sterk overeenkomen met de functiekenmerken uit meting 2008. Zo werkt van het huidige cohort $64 \%$ met een vaste aanstelling (SIS 2008: 67\%), heeft 70\% (SIS 2008: 70\%) een baan in het eigen domein (d.w.z. een functie waarin de gevolgde of een verwante opleidingsrichting is vereist) en werkt 73\% (SIS: 2008: 75\%) in een functie waarvoor minimaal het eigen opleidingsniveau is vereist. Met uitzondering van de gediplomeerden van het mbo-bbl niveau I/2 (wat de richting en het niveau betreft) en de gediplomeerden van het mbo-bol niveau I/2 (wat het niveau betreft) mag dan ook vastgesteld worden dat ook in tijden van een economische crisis de aansluiting qua richting en niveau als goed gezien kan worden.

Tabel 4.4 laat vervolgens zien dat de gediplomeerden mbo gezondheidszorg en mbo gedrag \& maatschappij aanzienlijk vaker in het eigen opleidingsdomein en op het eigen opleidingsniveau terecht komen dan de gediplomeerden van de andere mbo-opleidingsectoren. Vooral de gediplomeerden van de mbo-opleidingsectoren economie en landbouw werken relatief vaak, zij het gedwongen dan wel vrijwillig, buiten hun eigen domein. Ook dit lijkt echter niet direct een implicatie van de economische crisis te zijn, maar eerder een structureel gegeven.

Tabel 4.4

Kenmerken van de huidige functie naar opleidingssector in het mbo (\%)

\begin{tabular}{lccc} 
& Vaste aanstelling & Eigen domein & Eigen niveau \\
\hline landbouw & & & \\
techniek & 74 & 62 & 69 \\
economie & 63 & 67 & 65 \\
gezondheidszorg & 64 & 56 & 63 \\
gedrag \& maatschappij & 66 & 85 & 87 \\
Bron: Quickscan 2009, ROA & 60 & 83 & 83
\end{tabular}

De laatste indicator voor de kwaliteit van het werk die we bespreken is de beloning. Tabel 4.5 laat het bruto maandinkomen zien van de werkende mbo-gediplomeerden en het gemiddeld aantal uren dat zij per week werken. Ook hier zijn ter vergelijking de cijfers uit de meting van 2008 (gediplomeerden van het schooljaar 2006/2007) opgenomen. De bruto maandsalarissen blijken niet echt te verschillen tussen de twee metingen. Dit komt door a) een stijging van de beginsalarissen tussen 2008 en 2009 waarvan de jongeren uit meting 2009 profiteren en b) het 
feit dat de jongeren uit meting 2008 rond I jaar meer werkervaring hebben dan de jongeren uit meting 2009, waarvan de jongeren uit meting 2008 profiteren. De twee effecten blijken elkaar te compenseren. De cijfers tonen verder dat de gemiddeld oudere bbl'ers meer verdienen dan afgestudeerden van de bol, en dat er een redelijk rendement voortvloeit uit het behalen van een hoger opleidingsniveau.

Tabel 4.5

Salaris en aantal uren werkzaam naar opleidingstype en -niveau in het mbo

\begin{tabular}{|c|c|c|}
\hline & Bruto maandsalaris $(€)$ & Wekelijks aantal uren \\
\hline bol $1 / 2$ & 900 & 33 \\
\hline bol 3/4 & 1.269 & 31 \\
\hline bbl $1 / 2$ & 1.541 & 34 \\
\hline bbl $3 / 4$ & 1.657 & 32 \\
\hline Totaal & 1.441 & 32 \\
\hline SIS 2008 mbo totaal & 1.462 & 33 \\
\hline
\end{tabular}

Bruto maandsalaris afgerond op $€ 10$.

Bron: SIS 2008 / Quickscan 2009, ROA

De uitsplitsing van het bruto maandinkomen van de werkende mbo-gediplomeerden en het gemiddeld aantal uren dat zij per week werken naar gevolgde opleidingssector in het mbo laat zien dat de gediplomeerden mbo techniek het gemiddeld hoogste maandinkomen hebben: zij werken ook gemiddeld het grootste aantal uren per week (tabel 4.6). Ondanks dat de technici per maand daarom een circa $30 \%$ hoger salaris ontvangen dan de gediplomeerden van de sector gezondheidszorg, verdienen zij per uur zelfs iets minder.

\section{Tabel 4.6}

Salaris en aantal uren werkzaam naar opleidingssector in het mbo

\begin{tabular}{|lll|} 
& Bruto maandsalaris $(€)$ & Wekelijks aantal uren \\
\hline landbouw & & 35 \\
\hline techniek & 1.460 & 37 \\
\hline economie & 1.720 & 34 \\
\hline gezondheidszorg & 1.350 & 28 \\
\hline gedrag \& maatschappij \\
Bruto maandsalaris afgerond op $€$ 10.
\end{tabular}

Bron: Quickscan 2009, ROA 


\section{Noch studie noch werk}

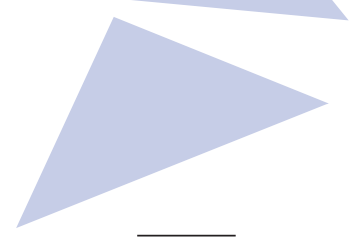

\section{$5.1 \quad$ Inleiding}

I $2 \%$ van de jongeren die aan de enquête hebben deelgenomen is op het moment van de enquête (oktober 2009) noch werkzaam noch met een studie bezig. Deze groep bestaat uit jongeren die of op zoek naar werk zijn of zich (tijdelijk) teruggetrokken hebben van de arbeidsmarkt zonder met een opleiding gestart te zijn. Aangezien het hier om een redelijk klein aantal respondenten gaat (I2\% van de onderzoekspopulatie), wordt in de tabellen slechts een onderscheid gemaakt tussen de twee opleidingstypen (bol versus bbl) en tussen de opleidingsniveaus (I/2 versus $3 / 4$ ).

Om te beginnen laat tabel 5.I zien dat rond twee op de drie jongeren van deze groep tussen het behalen van het mbo-diploma en oktober 2009 wel eens betaald werk heeft verricht. Overigens dient te worden opgemerkt dat het hierbij ook om een vakantiebaantje kan gaan. Er komt geen verschil tussen de gediplomeerden van het mbo-bol en de gediplomeerden van het mbo-bbl naar voren, en geen significante verschillen tussen de gediplomeerden van de verschillende opleidingssectoren. Wel blijkt er wat dit betreft een duidelijk verschil te bestaan naar niveau: gediplomeerden op niveau 3/4 (bol en bbl) hebben met 75\% duidelijk vaker ooit betaald werk verricht tussen het behalen van het diploma en oktober 2009 dan gediplomeerden op niveau I/2 (bol en bbl): $57 \%$. Dit onderstreept eens te meer het belang voor jongeren om zich zo hoog mogelijk te kwalificeren in onze kennisintensieve samenleving.

\section{Tabel 5.1}

Ooit betaald werk verricht tussen behalen van diploma en oktober $2009(\%)$

$\begin{array}{lcc} & \text { Ja } & \text { Nee } \\ \text { bbl } & 66 & 34 \\ \text { bol } & 66 & 34\end{array}$

Bron: Quickscan 2009, ROA

Uitgesplitst naar etniciteit blijkt dat van de jongeren die op het moment van de enquête noch werkzaam noch met een studie bezig zijn, de autochtonen met $73 \%$ het vaakst ooit betaald werk hebben verricht en de westerse allochtonen met $47 \%$ het minst vaak. Niet-westerse allochtonen nemen met $58 \%$ een tussenpositie in. Hierbij doet zich geen significant verschil tussen mannen en vrouwen voor. 
De jongeren geven echter wel duidelijk aan dat ze in de tijd tussen het behalen van het mbo-diploma en het moment van de enquête vaak al een aanzienlijke werkloosheidsduur kennen. Zo is $42 \%$ van hen in totaal langer dan 3 maanden werkloos geweest (mbo-bol: 41\%; mbo-bbl: 43\%). Van de jongeren die in totaal langer dan 3 maanden werkloos zijn geweest had $34 \%$ aan de school toestemming gegeven om hun gegevens aan het UWV door te geven. Van de jongeren die in totaal langer dan 3 maanden werkloos zijn geweest en die zelf met het UWV contact hebben opgenomen of door het UWV zijn benaderd, kreeg 58\% hulp aangeboden van het UWV.

\subsection{Toekomstplannen}

Tot slot is aan de groep die op het moment van de enquête noch werkzaam is noch met een opleiding bezig is, gevraagd wat hun directe toekomstplannen zijn (tabel 5.2). Een op de tien begint in de nabije toekomst met een opleiding en nog eens I2\% wil op zoek gaan naar een opleiding. $8 \%$ kan op korte termijn beginnen te werken. $22 \%$ wil via het UWV werk vinden en $31 \%$ doet dat liever zelf. Opvallend is daarbij dat zich een duidelijk verschil voordoet tussen de gediplomeerden van het mbo-bbl en de gediplomeerden van het mbo-bol. De eerste groep denkt aanzienlijk vaker $30 \%$ versus $18 \%$ ) om via het UWV werk te gaan zoeken, terwijl de tweede groep liever zelfstandig op zoek naar werk gaat. Hier zal zeker het duidelijke verschil in leeftijd een belangrijke rol kunnen spelen.

\section{Tabel 5.2}

Plannen voor de nabije toekomst, naar opleidingstype (\%)

\begin{tabular}{lccc} 
& mbo-bbl & mbo-bol & mbo-totaal \\
\hline Ik ga op korte termijn beginnen met een opleiding & 7 & 11 & 10 \\
Ik ga op zoek naar een opleiding & 17 & 11 & 12 \\
\hline Ik begin binnenkort met een baan & 4 & 10 & 8 \\
\hline Ik ga via het UWV op zoek naar werk & 30 & 18 & 22 \\
Ik ga zelfstandig op zoek naar werk & 25 & 33 & 31 \\
\hline Dat weet ik nog niet & 18 & 17 & 17
\end{tabular}

Bron: Quickscan 2009, ROA

Tabel 5.3 toont dat de directe toekomstplannen van de groep die noch werkzaam is noch verder onderwijs volgt vaker zijn gericht op werken dan op verder leren. Hierbij zijn de directe toekomstplannen van de lager niveau opgeleiden relatief vaker gericht op vervolgonderwijs en die van de hoger niveau opgeleiden op de arbeidsmarkt. Wat de directe toekomstplannen betreft zijn de gemeten verschillen naar opleidingssector, etniciteit of geslacht niet significant. 
Tabel 5.3

Plannen voor de nabije toekomst, naar opleidingsniveau (\%)

\begin{tabular}{lccc} 
& niveau 1/2 & niveau 3/4 & mbo-totaal \\
\hline Ik ga op korte termijn beginnen met een opleiding & 14 & 6 & 10 \\
\hline Ik ga op zoek naar een opleiding & 19 & 6 & 12 \\
\hline Ik begin binnenkort met een baan & 7 & 9 & 8 \\
\hline Ik ga via het UWV op zoek naar werk & 21 & 22 & 22 \\
\hline Ik ga zelfstandig op zoek naar werk & 24 & 38 & 31 \\
\hline Dat weet ik nog niet & 14 & 20 & 17
\end{tabular}

Bron: Quickscan 2009, ROA

Aan de groep jongeren die niet binnenkort met een opleiding start of niet op zoek gaat naar een opleiding is gevraagd wat de redenen zijn om dit niet te doen (zie tabel 5.4). De respondenten konden daarbij meerdere antwoorden geven. I6\% van degenen met een mbo-bol diploma zegt dat 'niet weten welke opleiding' een van de redenen was. Bij de gediplomeerden van het mbo-bbl is dit duidelijk minder vaak het geval, namelijk IO\%. Dit resultaat komt overeen met een onderzoek onder ongediplomeerde schoolverlaters. Hieruit kwam naar voren dat ongediplomeerden van de bol (niveau I/2: I8\%; niveau 3/4: 20\%) vaker dan ongediplomeerden van de bbl (niveau I/2: $9 \%$; niveau 3/4: $15 \%$ ) aangeven geen andere opleiding te gaan volgen omdat ze niet wisten welke opleiding (ROA, 2009: Zonder diploma, Aanleiding, Kansen en Toekomstintenties).

Niet verrassend geven de respondenten vaak aan dat ze 'liever gaan werken' en dat 'de kosten te hoog zijn'. Ook zeggen 4 van de Io respondenten dat ze een inkomen nodig hebben. Verder valt op dat er een duidelijk verschil is tussen de jongeren die de afgelopen jaren voor circa $80 \%$ op school zaten (bol) en de jongeren die voor circa $80 \%$ werkten (bbl) qua 'zin in school'. De eerste groep heeft duidelijk minder zin om verder naar school te gaan dan de tweede groep.

Tot slot dient te worden opgemerkt dat $\mathrm{I} 4 \%$ van de mbo-bbl gediplomeerden zegt dat er geen geschikte bbl-leerplaats voorhanden is. Dit geeft eens te meer aan hoe belangrijk het is om voldoende bbl-plaatsen in stand te houden.

Resumerend komt uit tabel 5.4 naar voren dat vooral de hoge kosten, de noodzaak om een inkomen te hebben en het feit dat men liever wil werken het overgrote deel van deze jongeren tegen houdt om aan een nieuwe opleiding te beginnen. Dit laat onverlet dat door betere studiekeuzevoorlichting en activiteiten voor meer stageplaatsen nog wel wat leerlingen alsnog voor vervolgonderwijs zijn te winnen. 
Tabel 5.4

Redenen om niet met nieuwe opleiding te starten (\%)

\begin{tabular}{lccc} 
& mbo-bbl & mbo-bol & mbo-totaal \\
\hline Ik weet niet welke opleiding & 10 & 16 & 15 \\
\hline Er is geen geschikte MB0-BBL plaats & 14 & 6 & 8 \\
\hline Er zijn geen interessante opleiding bij mij in de buurt & 0 & 3 & 2 \\
\hline De kosten zijn te hoog & 26 & 26 & 26 \\
Ik wil liever werken & 29 & 36 & 34 \\
\hline Ik heb een inkomen nodig & 43 & 41 & 17 \\
Ik heb geen zin meer in school & 5 & 21 & 7 \\
In principe niets & 6 & 7 & \\
Meerdere antwoorden mogelijk & & &
\end{tabular}

Tot slot is nagegaan of er nog opvallende verschillen naar opleidingsniveau, opleidingssector, etniciteit en geslacht zijn met betrekking tot de redenen om niet met een nieuwe opleiding te starten. Ook hierbij komt het belang van een voldoende groot aanbod van bbl-plaatsen nog eens naar voren. Zo geven lager niveau opgeleiden en gediplomeerden mbo techniek vaker dan anderen aan niet met een nieuwe opleiding te starten omdat er geen geschikte mbo-bbl plaats voor hen is. Westerse allochtonen geven vaker dan anderen aan niet met een nieuwe opleiding te starten omdat er geen interessante opleidingen bij hen in de buurt zijn, en autochtonen omdat zij geen zin meer hebben in school. Tot slot geven vrouwen vaker dan mannen aan niet met een nieuwe opleiding te starten omdat de kosten te hoog zijn. 


\section{Contacten met het UWV}

In dit hoofdstuk staan we tot slot stil bij de contacten die de respondenten hebben gehad met het UWV. Tabel 6.I laat zien dat circa $80 \%$ van de jongeren sinds het behalen van het diploma geen contact met het UWV heeft gehad, maar dat dit volgens hen ook niet noodzakelijk was. Dit is niet verrassend aangezien het gros van de mbogediplomeerden of met een vervolgopleiding gestart is of werkzaam is. $\mathbf{2} 2 \%$ geeft aan dat ze geen contact hebben gehad, maar dat ze zo een contact wel fijn zouden vinden. $9 \%$ heeft wel degelijk contact gehad, waarvan 5\%-punt zelf met het UWV contact heeft opgenomen en $4 \%$-punt door het UWV is benaderd.

Van de jongeren die niet door het UWV zijn benaderd is IO\% werkloos (gemiddelde werkloosheidsduur: 3,7 maanden). ${ }^{6}$ Van deze werkloze jongeren had $39 \%$ aan de school toestemming gegeven om hun gegevens aan het UWV door te geven.

Tabel 6.I geeft ook de cijfers op basis van een onderscheid in een drietal groepen van jongeren, namelijk de jongeren die op het moment van de enquête werkzaam zijn, de jongeren die een opleiding volgen en de jongeren die noch werkzaam noch studerend zijn (categorie 'anders').

Tabel 6.1

Contact met het UWV naar huidige situatie (\%)

\begin{tabular}{lcccc} 
& Volgt opleiding & Is werkzaam & Anders & Totaal \\
\hline Nee, maar dat is ook niet nodig & 83 & 84 & 48 & 79 \\
$\begin{array}{l}\text { Nee, maar dat zou ik wel fijn } \\
\text { vinden }\end{array}$ & 12 & 9 & 24 & 12 \\
$\begin{array}{l}\text { Ja, ik heb het UWV zelf benaderd } \\
\text { Ja, het UWV heeft mij benaderd }\end{array}$ & 2 & 4 & 19 & 5 \\
Bron: Quickscan 2009, ROA & 3 & 3 & 9 & 4
\end{tabular}

Niet verrassend vindt het gros van de jongeren die een opleiding volgen of werkzaam zijn het niet nodig om met het UWV in contact te komen. Van de jongeren die noch werkzaam zijn noch een opleiding volgen vindt een aanzienlijk kleiner deel het niet nodig, maar ook hier is het nog bijna één op de twee. Dit spoort gedeeltelijk met de eerdere bevinding dat een deel van deze jongeren al binnenkort met een opleiding dan wel een betaalde baan begint, en dat daarnaast bijna één op de drie zelfstandig op zoek

6. Van de jongeren die wel in contact zijn gekomen met het UWV was $46 \%$ werkloos (gemiddelde werkloosheidsduur 3,3 maanden). 
gaat naar werk. Blijven we bij de groep die noch werkzaam is noch een opleiding volgt dan zien we dat $24 \%$ het wel fijn zal vinden als het UWV hen zou benaderen. Maar ook in de andere groepen van respondenten vinden we dat er jongeren zijn die het fijn hadden gevonden als het UWV hen benaderd had. Zo zegt I2\% van de jongeren die nu een opleiding volgen dat ze graag door het UWV waren benaderd, en is het in de groep van de werkende mbo-gediplomeerden nog steeds bijna één op de tien.

Het lijkt er in eerste instantie op alsof het UWV hier nog aanzienlijk wat werk te verrichten heeft. Bij een nadere analyse blijkt echter dat van de groep die aangeeft dat ze geen contact hebben gehad maar dit fijn hadden gevonden, bijna $80 \%$ aan de school geen toestemming heeft gegeven om hun gegevens aan het UWV door te geven. Het lijkt ons dan ook van belang om in de toekomst bij een eventueel vervolg op het School-Ex Programma, scholieren duidelijk te maken dat het van belang is hier toestemming voor te geven.

Ter vergelijking: van de jongeren die wel met het UWV contact hebben gehad, heeft circa 50\% toestemming gegeven. De andere 50\% blijkt zelfstandig of via hulp van derden in contact met het UWV gekomen te zijn. Kijken we naar de vraag of het UWV contact heeft gehad met de respondenten op het niveau van provincies, dan zien we dat er een duidelijk positieve relatie is tussen het werkloosheidspercentage in een provincie en het percentage dat contact met het UWV had. Met andere woorden, hoe hoger het arbeidsmarktprobleem in een provincie des te hoger het percentage jongeren dat met het UWV in contact is. Op dezelfde wijze bestaat er een duidelijke positieve relatie tussen het werkloosheidspercentage in een provincie en het percentage dat het jammer vindt dat ze nog geen contact hebben gehad.

Van de jongeren die contact met het UWV hebben gehad, zegt 60\% dat het UWV hulp heeft aangeboden:

- Van deze groep was 50\% werkloos (gemiddeld 3,2 maanden werkloos).

- Van deze groep kunnen we verder in kaart brengen welke 'activiteit' zij samen met het UWV hebben gedaan. Tabel 6.2 geeft van een aantal onderscheiden activiteiten het percentage aan dat deze activiteit heeft gehad.

Tabel 6.2

Activiteit naar aanleiding van contact met UWV (\%)

\begin{tabular}{lc|}
\hline Activiteit & $\%$ ja \\
\hline Intakegesprek (gehad of heb dit binnenkort) & 69 \\
\hline Aanbod ontvangen voor baan/leerplaats & 26 \\
\hline Cursus/training aangeboden & 14 \\
\hline Cursus/training gevolgd of volgen binnenkort & 7 \\
\hline Bezoek gebracht aan banenmarkt & 21 \\
\hline Beroepskeuzetest gedaan & 12 \\
\hline
\end{tabular}

Meerdere antwoorden mogelijk

Bron: Quickscan 2009, ROA 
Circa 70\% van de jongeren die contact hebben gehad met het UWV heeft al (of heeft dit binnenkort) een intakegesprek gehad en één op de vier heeft ook al een aanbod ontvangen voor een baan/leerplaats. Daarnaast heeft één op de vijf via het UWV een banenmarkt bezocht, is I4\% een cursus/training aangeboden en heeft I $2 \%$ een beroepskeuzetest gedaan.

Hoe succesvol waren de activiteiten van het UWV tot nu toe? De resultaten in tabel 6.3 laten zien dat bijna $20 \%$ van de jongeren die hulp van het UWV hebben gekregen, aangeeft dat de ondersteuning daadwerkelijk geholpen heeft. Aangezien echter $28 \%$ ook nog aangeeft dat het niet geholpen heeft maar dit ook niet meer nodig was, kan het succescijfer zelfs nog hoger worden ingeschat. Bijna één op de twee geeft echter te kennen dat de ondersteuning (nog) niet geholpen heeft. Opvallend is daarbij dat $22 \%$ van de jongeren aangeeft dat de ondersteuning niet heeft geholpen en dat ze ook geen contact meer met het UWV hebben.

\section{Tabel 6.3}

Heeft de ondersteuning van het UWV geholpen? (\%)

\begin{tabular}{|ll|}
\hline Activiteit & $\%$ ja \\
\hline Ja & 20 \\
\hline Nee, maar dat was ook niet (meer) nodig & 28 \\
\hline Nee, maar ik heb nog contact met het UWV & 31 \\
\hline Nee, en ik heb geen contact meer met het UWV & 22 \\
\hline
\end{tabular}

Bron: Quickscan 2009, ROA 